\author{
UNIVERSIDADE DE SÃO PAULO \\ FACULDADE DE ZOOTECNIA E ENGENHARIA DE ALIMENTOS
}

CARLOS EDUARDO OLIVIERI

Caminhos para a prática contábil do ativo biológico em pequenas e médias propriedades rurais. 
CARLOS EDUARDO OLIVIERI

Caminhos para a prática contábil do ativo biológico em pequenas e médias propriedades rurais.

(Versão Corrigida)

Dissertação apresentada à Faculdade de Zootecnia e Engenharia de Alimentos da Universidade de São Paulo, como parte dos requisitos para obtenção do Título de Mestre em Ciências com ênfase em Gestão e Inovação na Indústria Animal.

Área de Concentração: Gestão e Inovação na Indústria Animal

Orientador: Prof. Dr. Luís Fernando Soares Zuin 


\section{Caminhos para a prática contábil do ativo biológico em pequenas e médias propriedades rurais.}

Dissertação apresentada à Faculdade de Zootecnia e Engenharia de Alimentos da Universidade de São Paulo, como parte dos requisitos para a obtenção do Título de Mestre em Ciências com ênfase em Gestão e Inovação na Indústria Animal.

Área de Concentração: Gestão e Inovação na Indústria Animal

Data de aprovação: $/ 2021$

\section{Banca Examinadora:}

Prof. Dr. Luís Fernando Soares Zuin

Prof.

Prof.

Prof. 
FICHA CATALOGRÁFICA

Ficha catalográfica elaborada pelo

Serviço de Biblioteca e Informação, FZEA/USP,

com os dados fornecidos pelo(a) autor(a)

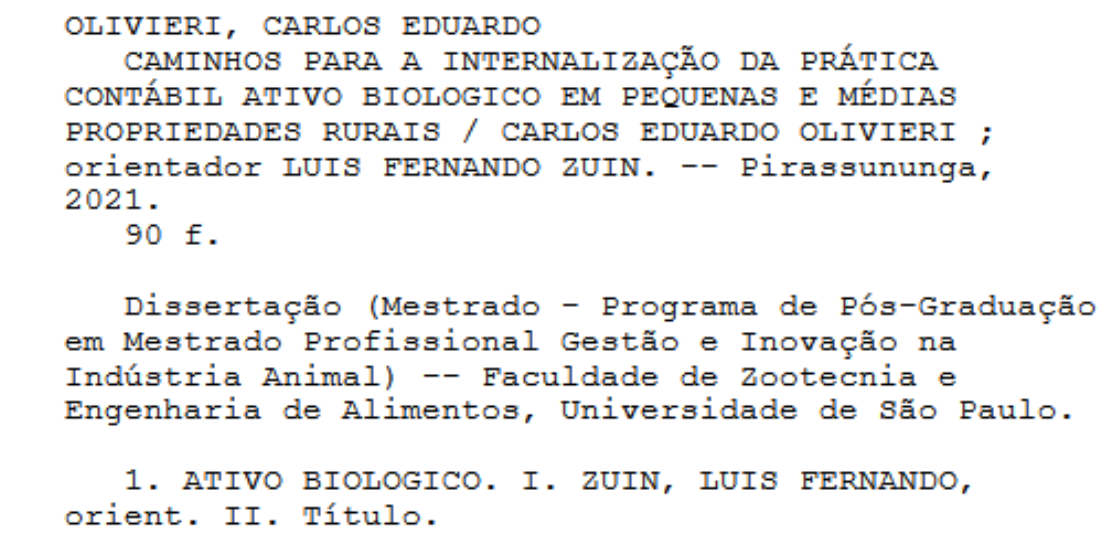

Permitida a cópia total ou parcial deste documento, desde que citada a fonte - o autor 


\section{DEDICATÓRIA}

Aos meus familiares que sempre estiveram ao meu lado, incentivando, indicando caminhos a seguir, dando todo o suporte necessário para que obtivesse a conclusão deste título de singular importância acadêmica, e foram fundamentais nesta empreitada, meu enteado Luiz Fernando Cilurzo e minha esposa Creuza Gazotti Cilurzo, a vocês minha eterna gratidão.

Ao meu Orientador, Prof. Dr. Luis Fernando Soares Zuin, que contribuiu de forma singular no direcionamento da dissertação, de seus conselhos acadêmicos lastreados em seu saber a respeito de produtores agrícolas, na indicação de profissionais a serem entrevistados e de onde poderia obter os dados para lastrear a dissertação, conduziu-me em caminhos pavimentados por um verdadeiro mestre com seu discípulo e que terá minha eterna gratidão. 


\section{AGRADECIMENTOS}

Ao Deus Pai Todo Poderoso, que sendo onisciente e onipresente, atendeu minhas necessidades e concedeu-me as forças necessárias que precisava e concedeu-me para cumprir com as obrigações exigidas e a meu lado, auxiliou-me na conclusão deste importante trabalho do universo acadêmico e que representa vencer uma enorme etapa na minha vida pessoal e profissional

A minha família que, que ao longo deste percurso, incentivou-me, ofereceu o apoio e sustentação necessária de maneira equânime para que chegasse ao final desta importante conquista acadêmica. Apoiaram a minha ausência, para a frequência das aulas, das pesquisas, das entrevistas, e do período de escrita da dissertação. Principalmente a minha esposa Creuza Gazotti Cilurzo, que incessantemente e de seu modo peculiar incentivou, ajudou e cooperou por esta minha intensa e longa jornada acadêmica.

Ao meu Professor e Orientador, Dr. Luis Fernando Soares Zuin, que com sua sabedoria, indicou-me os direcionamentos essenciais para a sua plena realização e melhoria em todos os aspectos desta dissertação, transmitindo os conhecimentos importantes para meu crescimento pessoal, intelectual e profissional, além de ter sido um incentivador no transcurso desta dissertação, indicou pessoas, pavimentou meus caminhos e com extrema paciência conduziu-me por um universo de sua sapiência na condução de um discípulo e alimentou uma amizade que certamente ficará para todo o sempre.

Ao corpo docente da Faculdade de Zootecnica e Engenharia de Alimentos na área de concentração, Gestão e Inovação na Indústria Animal, que pela competência e capacidade, souberam repassar os conteúdos fundamentais para minha formação neste curso.

O presente trabalho foi realizado com 0 apoio da Coordenação de Aperfeiçoamento de Pessoal de Nível Superior (CAPES-Brasil).

Aos colegas de classe, que ao longo das aulas da Pós-Graduação, com seus conhecimentos, know how profissional, amizade, coleguismo, com material e direcionamento, e especialmente para o Adilson Lançoni, que ajudou-me com seus conhecimentos da matéria e que embasou minha dissertação e auxiliou ao longo do 
caminho, ao Fábio Sciamana e a Ana Cristina Ushima, que além do incentivo pessoal, das caronas e da amizade que foi firmada ao longo do percurso e criado um vínculo que também será para todo o sempre.

E derradeiramente, a todos que de forma direta e indireta participaram e contribuíram e incentivaram para a obtenção deste importante e singular título, sempre vão estar em minha memória e as quais deixo meu mais efusivo agradecimento por suas ações. 
Não podemos prever o futuro, mas podemos criá-lo.

Peter Drucker 


\section{RESUMO}

Este estudo possui o objetivo de diagnosticar e propor encaminhamentos metodológicos didáticos visando a internalização da prática contábil denominada Ativo Biológico nas rotinas produtivas de propriedades rurais de pequeno e médio porte, localizadas nas cidades que compõem a Escritório de Desenvolvimento Regional da cidade de Limeira (EDR-SP) e da Coordenadoria de Desenvolvimento Rural Sustentável (CDRS-SAA-SP). Para a concretização deste objetivo serão percorridos dois caminhos metodológicos, o primeiro por meio da realização de um conjunto de entrevistas com especialistas contábeis, extensionistas e produtores rurais, onde se irá coletar conjuntos de relatos e informações sobre como realizar a prática contábil na propriedade rural. A realização e análises destes conjuntos de entrevistas que será empregado o método de coleta de dados e informações o estudo de caso por meio da oferta de um roteiro de pesquisa com questões fechadas e semiabertas, para um conjunto de entrevistados. O segundo caminho se dará por meio dos conteúdos científicos coletados na literatura especializada, relativos aos temas da pesquisa como os caminhos didáticos para o uso de novas tecnologias nos territórios rurais, práticas contábeis e ativo biológico. A análise dos conteúdos coletados nas entrevistas a luz do referencial teórico terá como um dos resultados o desenvolvimento de encaminhamentos metodológicos didáticos, que visam a adoção da tecnologia contábil do Ativo Biológico nas rotinas produtivas de pequenos e médios produtores rurais. Com essas práticas contábeis espera-se que o produtor rural aumente a sua renda, contribuindo com a sua sobrevivência.

Palavras-chaves: Ativo Biológico. Contabilidade. Adoção de novas tecnologias. 


\begin{abstract}
This study aims to diagnose and propose didactic methodological referrals aiming at the internalization of the accounting practice called Biological Asset in the productive routines of small and medium sized rural properties, located in the cities that make up the Limeira Regional Development Office (EDR). Sustainable Rural Development Coordination (CDRS-SAA-SP). In order to achieve this objective, two methodological paths will be followed, the first by conducting a set of interviews with accounting specialists and rural extensionists, which will collect sets of reports and information on how to internalize this practice in rural property. The conduction and analysis of these sets of interviews will be used the case study (YIN, 2010), through a research script with closed and semi-open questions. The second path will be through the scientific contents collected in the specialized literature, related to research topics such as the didactic paths of the internalization of new technologies in rural territories (ZUIN et al, 2019; BATALHA; SILVA, 2007), accounting practices (PADOVEZE, 2016) and biological asset (NOGUEIRA; PIRES, 2017). The analysis of the contents collected in the interviews in the light of the theoretical framework will have as one of the results the development of didactic methodological referrals, aiming at the internalization of the accounting technology of the Biological Asset in the productive routines of small and medium rural producers. With this internalization, the rural producer is expected to increase his income, contributing to his survival.
\end{abstract}

Keywords: Biological Asset. Accounting. Internalization of news technologies. 


\section{LISTA DE QUADROS}

Quadro 1 - Exemplos de Ativos Biológicos, Produtos Agrícolas e seus resultados depois do processamento 36 


\section{LISTA DE TABELAS}

Tabela 1 - Produção animal média anual dos principais ativos biológicos presentes na EDR da região da cidade de Limeira (SP) 55

Tabela 2 - Principais explorações animais na EDR de Limeira (SP) 2016/17 55 


\section{LISTA DE ABREVIATURAS E SIGLAS}

CNC Comissão de Normalização Contabilística

CDRS Coordenadoria de Desenvolvimento Rural Sustentável

CPC Comitê de Pronunciamentos Contábeis

EDR Escritório de Desenvolvimento Regional

IAS International Accounting Standards

IASB International Accounting Standard Board

IRFS Normas Internacionais de Contabilidade

NCRF Norma Contabilística e de Relato Financeiro

SAA-SP Secretaria de Agricultura e Abastecimento do Estado de São Paulo

SNC Sistema de Normalização Contabilística

SP São Paulo

DRE Demonstrativo do Resultado do Exercício

DFC Demonstrativo do Fluxo de Caixa

TDICs Tecnologias Digitais de Informação e Comunicação

TICs Tecnologia da Informação e Comunicação

GPS Global Positioning System

SIG Sistema de Informação Geográfico

TI Tecnologia da Informação 


\section{SUMÁRIO}

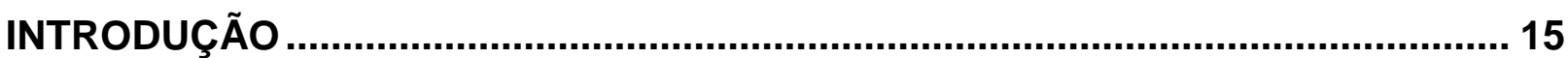

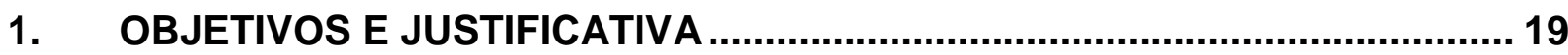

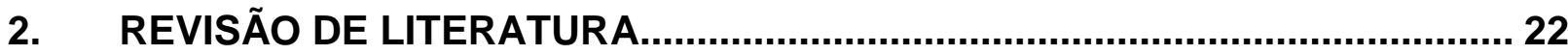

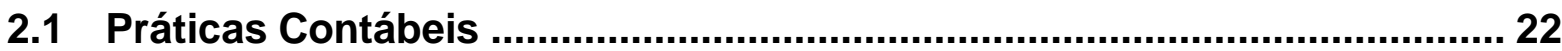

2.2 Contabilidade: conceitos, finalidades e objetivos ................................... 23

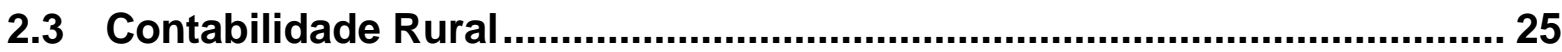

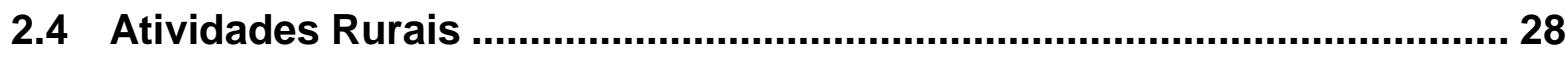

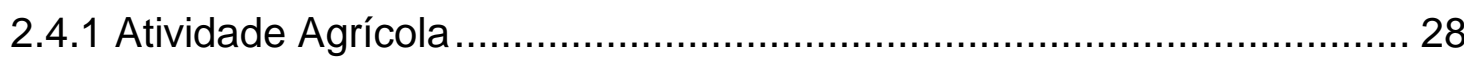



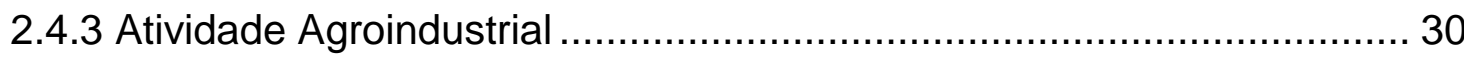

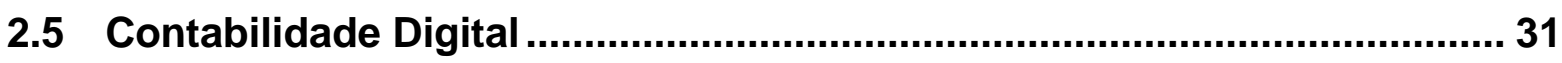

2.6 Comissão de Normalização Contabilística 29 …......................................... 33

2.6.1 Ativos Biológicos e Produtos Agrícolas................................................ 35

2.6.2 As controvérsias entre o Custo Histórico e o Valor Justo ........................ 37

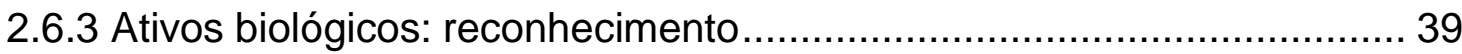



2.6.5 Ativos biológicos: evidenciação ...................................................... 433

3. AS TECNOLOGIAS DA INFORMAÇÃO E COMUNICAÇÃO (TIC) NA PRODUÇÃO AGROPECUÁRIA ........................................................... 455

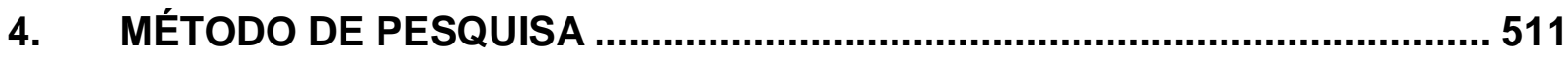

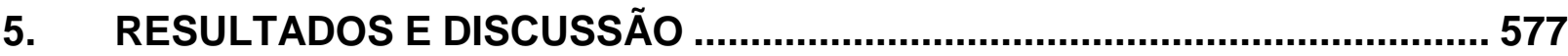

5.1 Características dos Contadores, Extensionistas e Produtores Rurais.. 577

5.2 Potencialidades e dificuldades para introdução do ativo biológico em propriedades rurais de pequeno porte .................................................... 588

5.3 A percepção dos entrevistados em relação ao Ativos Biológico ............600

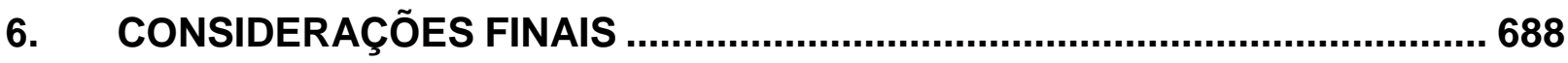

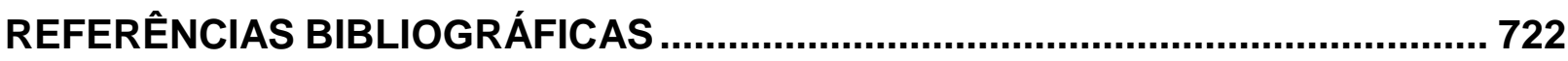

ANEXO 


\section{INTRODUÇÃO}

Historicamente, a atividade contábil nas cadeias produtivas do agronegócio apresenta-se como um campo de interesse para os gestores e pesquisadores, envolvendo um conjunto de estudo e desenvolvimento de metodologias de gestão dos mais variados tipos de seus empreendimentos. $O$ desempenho das atividades contábeis apresenta embasamento em normas e procedimentos, os quais consideram a organização do patrimônio como objeto principal de mensuração e evidenciação (PEROVANO, 2016).

Também ao longo do tempo foram desenvolvidas, tanto pela academia como órgão reguladores, conjuntos de atividades contábeis que possuem como meta 0 ato de aprimorar a condução dos processos produtivos, como os contextos vivenciados nas rotinas produtivas nas organizações rurais (OLIVEIRA, 2014).

A Contabilidade é considerada uma ciência social que, em suas tratativas, apresenta o patrimônio de uma organização como objeto principal. Para fins contábeis, o patrimônio representa a concentração de riqueza de uma entidade, que por sua vez, é determinada pela especificação de algo. No tratamento contábil, uma entidade pode ser conceituada por meio de uma pessoa física ou jurídica. A ciência contábil possui o direcionamento para tratar 0 patrimônio das entidades caracterizadas como pessoas jurídicas (PADOVEZE, 2016).

O patrimônio ou riqueza de uma organização refere-se aos bens e direitos que o ser humano atribui a um determinado valor econômico, ou seja, são elementos possíveis de quantificação em unidades monetárias (como no caso do Brasil em reais). Por esta perspectiva, o patrimônio total de uma organização é a repercussão da soma do valor econômico de todas as riquezas desta entidade (PADOVEZE, 2016).

Este conceito evidência a necessidade de produzir uma informação contábil segura, fidedigna e transparente, buscando entre outros objetivos, auxiliar o processo de tomada de decisão econômica das organizações. Esse cenário levou o Brasil a adotar as Normas Internacionais de Contabilidade (IRFS), determinando as empresas nacionais brasileiras a aplicar as normas publicadas pelo Comitê de Pronunciamentos Contábeis (CPC).

Esta organização divulga suas condutas normativas em sintonia com os 
documentos emitidos pelo International Accounting Standards Board (IASB) que possuía atribuição de promover uma reflexão, diálogo e publicação de standards (padrões) para centralização da Contabilidade em grande parte dos países (NOGUEIRA; PIRES, 2017).

Entre os vários pronunciamentos publicados no Brasil, consta o CPC 29 Ativo Biológico e Produto Agrícola, o qual mantém relação com o International Accounting Standards 41 (IAS) - Agriculture que possui a responsabilidade de estabelecer a demarcação legal que norteia o entendimento, detalhamento, aferição e comprovação dos ativos biológicos pertencentes às organizações, que possuem este produto, como no caso das empresas rurais (NOGUEIRA; PIRES, 2017).

A alteração da forma de apresentação contábil, do pequeno e médio produtor rural da forma de livro caixa, para contabilidade formal, pode certamente, trazer-Ihe benefícios singulares na apresentação da garantia real, oriunda do ativo biológico, onde a mesma passa ser inserida na conta - Ativo Não Circulante, de seu balanço ou balancete, onde os atores do mercado: Instituições Financeiras Privadas e Públicas, na concessão de empréstimos, financiamentos, etc. a juros em melhores condições, tendo em vista a garantia real e das Companhias Seguradoras, melhoram as taxas de coberturas das apólices de seguro (NOGUEIRA; PIRES, 2017).

$\mathrm{Na}$ definição do que é uma atividade agrícola é importante conhecer o que a legislação brasileira classifica como tal, para então compreender a necessidade de realizar uma diferenciação de atividades nas organizações rurais, e que atividades irão ser classificadas como agrícolas, as quais farão parte do seu escopo contábil. Importante conhecer estas normas, lembrando que elas podem mudar, tanto o contador, como produtor rural e extensionista devem sempre se manter atualizados.

Pela Lei $8171 / 91$ no artigo $2^{\circ}$ inciso I, sendo:

A atividade agrícola compreende processos físicos, químicos e biológicos, onde os recursos naturais envolvidos devem ser utilizados e gerenciados, subordinando-se as normas e princípios de interesse público, de forma que seja cumprida a função social e econômica da propriedade (BRASIL,1991, s/p).

No documento relativo ao pronunciamento técnico CPC 29 - Ativo Biológico e Produto Agrícola (CPC 29, 2013, p.3) conceitua atividade agrícola como o 
"gerenciamento da transformação biológica e da colheita de ativos biológicos para venda ou para conversão em produtos agrícolas ou em ativos biológicos adicionais pela entidade".

A instrução Normativa da Receita Federal número 1700/2017, artigo 249, que revogou a SRF 257/2002 (RECEITA FEDERAL-BRASIL, 2017) relata que os caminhos que determinam a produção agropecuária são constituídos por atividades e operações de giro financeiro, que envolvem a pessoa jurídica, permeando a exploração da atividade rural, as quais incluem as operações de giro normal de uma pessoa jurídica, como resultados das atividades rurais, e confecciona uma lista do que pode e o que não pode ser considerado uma atividade rural. Na Normativa da Receita Federal o termo é "atividade rural" e não "atividade agrícola", mas os conceitos são equivalentes.

No pronunciamento IAS 41, no parágrafo 40 , relata que as organizações devem descrever em suas demonstrações contábeis, devidamente formalizadas, de maneira clara, distinguível e alocada na devida nomenclatura contábil com específica narrativa o grupo de ativo biológico, separando os mesmos em produtos que serão consumidos dos de produção, e também aqueles relativos à sua faixa etária (maduros ou adultos) daqueles que são imaturos e juvenis. Desta forma haverá uma alteração significativa do ponto de vista econômico-financeiro a ser avaliada pelos: bancos, governos, fornecedores, clientes e mercado dos balanços patrimoniais das empresas de médio e pequeno porte, ao serem avaliadas pelos seus números, apresentados com as garantias reais advindas do Ativo Biológico, lançado como um "Ativo Não Circulante", vislumbrando em seu conteúdo contábil, e significativa forma de números expressivos de garantias de operações financeiras. Os seus principais objetivos são: a proteção dos investidores; assegurar que os mercados sejam adequados, eficazes e confiáveis e a redução de risco do empreendimento. Também os pequenos e médios agricultores, que se incluem neste estudo, devem para seu benefício próprio efetuar, mesmo que a legislação não o obrigue, a categoria da contabilidade de forma específica, apenas pelo regimede caixa o qual não é suficiente, conforme determina a legislação vigente. E fazendo configurar em seu plano de contas do Ativo Não Circulante, o item do Ativo Biológico (CASTRO et al., 2015).

Para obter as benesses do mercado financeiro, dos fornecedores de 
insumos e dos clientes em potencial. E ainda obter taxas melhores, nos seguintes segmentos financeiros para pequenos e médios produtores rurais, como, por exemplo: Duplicata Rural; Cédula de Produtor Rural; Proer Rural; Programa Nacional de Fortalecimento da Agricultura Familiar; entre outros (CASTRO et al., 2015; SOUZA, 2013). 


\section{OBJETIVOS E JUSTIFICATIVA}

Este estudo teve como objetivo diagnosticar e propor encaminhamento didáticos que auxilie os produtores rurais e os profissionais de contabilidade à adoção da prática contábil denominada Ativo Biológico nas rotinas produtivas de propriedades rurais de pequeno e médio porte, localizadas nas cidades que compõem o Escritório de Desenvolvimento Regional (EDR-SP) da região da cidade de Limeira da Coordenadoria de Desenvolvimento Rural Sustentável (CDRS-SAASP). Para tanto, contou com os seguintes objetivos específicos:

i. levantamento da produção científica da prática contábil Ativo Biológico nas propriedades e também os possíveis caminhos didáticos para a sua internalização na produção agropecuária nacional;

ii. realizar junto a um conjunto de especialistas, em ciências contábeis e extensão rural, diagnósticos sobre as dificuldades e possíveis caminhos para a internalização da prática contábil Ativo Biológico em propriedades rurais de pequeno e médio porte pertencentes a EDR-CDRS-SP da região da cidade de Limeira; e

iii. propor encaminhamentos que auxilie produtores e profissionais de contabilidade internalização da prática contábil do Ativo Biológico em propriedades de pequeno e médio porte localizadas na região da EDR-CDRS-SP da região da cidade de Limeira.

No presente estudo houve a necessidade de realizar-se um ajuste no desenho do projeto, devido ao isolamento social que estamos sujeitos, nesse período iniciado em março de 2020, em virtude da pandemia do Coronavírus. Com o intuito de possibilitar a realização das entrevistas necessárias para a realização deste trabalho, verificou-se a possibilidade da realização de forma remota, como telefone, e-mail, vídeo-chamada, entre outras. Desta maneira, foi possível realizar não só com os contadores e extensionistas, conforme proposta inicial, como também acrescentar a possibilidade de entrevistas com mais dois produtores rurais. 
Diante disso, o objetivo é inserir os pequenos e médios produtores rurais na contabilidadegerencial formal.

A contabilidade gerencial é definida como uma ferramenta de gestão da empresa, quando esta pode enfatizar o sucesso de seu processamento. Os gestores precisam tomar decisões precisas e ágeis decisões para não transferirem certas oportunidades que a empresa possa ter, portanto, a contabilidade necessita de informações que não ocorrem em muitos escritórios de contabilidade. A situação real é que o contador está prestando serviços à autoridade tributária e, por fim, mostra aos usuários contábeis que o contador é apenas um agente fiscal.

Entretanto, a contabilidade gerencial é vista como uma ferramenta de gestão das empresas, e as supracitadas utilizam esses mecanismos para prever a eficácia de seus processos. Os gerentes precisam tomar decisões rapidamente para não perder as oportunidades que a organização possa ter. Para isso, são necessárias informações contábeis. Mas não é muito o que a gente vê no departamento contábil, porque o que se percebe são contadores que atendem ao fisco. Isso acabará por indicar aos usuários de contabilidade que é apenas um agente tributário. Mostra uma visão contábil sutil sem saber sua real importância, o que auxilia na tomada de decisão.

De acordo com Atkinson et al (2008, p. 37) "sistemas de contabilidade gerencial eficazes podem criar valor considerável pela informação a tempo e com precisão sobre as atividades exigidas para o sucesso das organizações de hoje." Os gestores visam atingir os resultados desejados, mas para tanto, as atividades devem ser corretamente monitoradas. O sistema de contabilidade gerencial propicia a organização o controle dessas atividades, proporcionando atingir os resultados esperados.

De acordo com ludícibus (1986) as características da contabilidade gerencial podem ser uma atenção especial para várias técnicas e procedimentos contábeis que são conhecidos e processados na contabilidade financeira, de custos de produção, finanças entre outros. A característica da contabilidade gerencial é que ela pode utilizar dados de diferentes campos contábeis como informações para os administradores possam tomar decisões para o empreendimento com a menor margem de insegurança.

ludícibus (1986) ressalta que de maneira geral, pode-se dizer que quaisquer 
procedimentos, técnicas, informações ou relatórios contábeis formulados "na ordem" podem ser utilizados pela administração para tomar decisões ou avaliar desempenho entre alternativas conflitantes. Pertence à contabilidade gerencial $A$ corrupção informal, ativa e passiva limita o uso total da contabilidade. Para Barbosa (2006, p. 17) "não se pode imaginar o gerenciamento eficaz de uma célula social sem a presença da informação contábil". A função da contabilidade gerencial é auxiliar o controle organizacional, melhorar o controle operacional, analisar custos e melhorar os níveis estratégicos.

Jiambalvo (2002 p. 4) afirma que a "contabilidade gerencial enfatiza as informações que são úteis aos gerentes internos para o planejamento, o controle e a tomada de decisão." Portanto, o contador gerencial pode organizar os dados, analisálos e medi-los para que o gerente tenha um entendimento correto da situação geral para que ele possa tomar decisões mais específicas, e até mesmo orientar o gerente para que ele saiba onde proceder Investimento e se há algum problema, de forma a trazer a contabilidade para dentro da organização como uma ferramenta de gestão e exercer o controle real sobre a organização. 


\section{REVISÃO DE LITERATURA}

\subsection{Práticas Contábeis}

Em seus estudos Rosenfeld et al. (2006) observam que inovação nas organizações pode possuir várias origens, como por exemplo, por meio do desenvolvimento de novos produtos e processos. As organizações buscam a internalização de processos inéditos através da internalização de novas formas de conduzir o empreendimento, por meio da adoção de práticas de gestão, como no caso deste estudo as práticas contábeis do Ativo Biológico.

Como observou em seus estudos Batalha e Silva (2007), a sobrevivência de pequenas e médias propriedades rurais brasileiras passa necessariamente pelo desenvolvimento de práticas de gestão, que visam a coleta frequente de dados e informações das rotinas vivenciadas nos seus processos produtivos. Conjuntos de dados e informações que envolvem conjuntos de indicadores de produtividade como, por exemplo, os seus custos de produção, armazenamento e comercialização.

Em seus estudos Vale e Silva (2019) e Almeida e Anjos (2018) observam a importância da introdução da contabilidade rural para a melhora do gerenciamento das rotinas produtivas, auxiliando o processo de tomada de decisão do produtor rural de pequeno porte, buscando o aumento da sua renda. A contabilidade rural seria uma ferramenta de gestão que busca desenvolver um ambiente produtivo menos incerto nos territórios rurais, possibilitando ao produtor rural um maior controle de suas atividades e, com isso, buscar aumentar a sua rentabilidade.

Entretanto, Almeida e Anjos (2018) relatam em seus estudos que as empresas as quais prestam serviços contábeis nos territórios rurais, relatam uma certa resistência pelos produtores rurais de pequeno porte em introduzir as práticas contábeis em suas rotinas produtivas. Os proprietários rurais desta categoria, na sua maioria, empregam uma contabilidade tributária simples e incompleta; para estes sujeitos, esta ferramenta gerencial aplicada de forma completa seria vista como uma imposição dos contadores. Esta imposição pode ser devida por outro resultado da pesquisa desses pesquisadores, onde relatam a falta de treinamento e experiência do profissional contador em se relacionar e atender as expectativas do produtor rural, 
causando discordância e insegurança durante a prestação deste serviço para esse sujeito. Desenvolver e internalizar tecnologias nas propriedades rurais é um desafio significativo para as organizações de extensão rural, tanto privadas como governamentais.

Para Zuin et al. (2019), um dos desafios para esses profissionais que interagem com os produtores rurais é a construção de caminhos internacionais que possam, junto e com os produtores rurais, desenvolver seus processos produtivos. Caminhos que vão desde conhecer as necessidades e desejos dos produtores rurais, até os significados e sentidos das palavras as quais permeiam todas suas vivências, não somente a produtiva.

Conhecer esses conjuntos de parâmetros dos seus sistemas produtivos, os quais refletem parte da realidade dos produtores rurais, é fundamental para o desenvolvimento de estratégias internacionais pedagógicas que buscam uma internalização conjunta de novas tecnologias nos territórios rurais, como no caso dos caminhos da prática contábil do ativo biológico.

\subsection{Contabilidade: conceitos, finalidades e objetivos}

Numa visão geral, a Contabilidade é uma ciência social e gerencial que possui o objetivo o conhecimento e o controle do patrimônio das entidades. Entretanto, a Contabilidade pode ser definida de diferentes maneiras.

De acordo com Marion (2017, p.3):

A Contabilidade pode ser estudada de modo geral (para todas as empresas) ou particular (aplicada a certo ramo de atividade ou setor da economia). Quando estudada de forma genérica, a Contabilidade é denominada Contabilidade Geral ou Contabilidade Financeira. Quando aplicada a um ramo específico, normalmente é denominada de acordo com a atividade daquele ramo. Assim, há:

2.2.1 Contabilidade Agrícola: é a Contabilidade Geral aplicada às empresasagrícolas;

2.2.2 Contabilidade Rural: é a Contabilidade Geral aplicada às empresas rurais;

2.2.3 Contabilidade da Zootécnica: é a Contabilidade Geral aplicada àsempresas que exploram a Zootécnica.

2.2.4 Contabilidade da Pecuária: é a Contabilidade Geral aplicada às empresaspecuárias;

2.2.5 Contabilidade Agropecuária: é a Contabilidade Geral 
aplicada àsempresas agropecuárias;

2.2.6 Contabilidade da Agroindústria: é a Contabilidade Geral aplicada àsempresas agroindustriais.

O autor supracitado ainda ressalta que a Contabilidade proporciona o máximo de dados importantes que são capazes de ajudar na tomada de decisão dentro ou fora da empresa.

Na interpretação de Sá (1998, p.42) "Contabilidade é a ciência que estuda os fenômenos patrimoniais, preocupando-se com realidades, evidências e comportamentos dos mesmos, em relação à eficácia das células sociais”. Já Jacinto (1990, p. 26) descreve a "Contabilidade como o estudo do patrimônio, suas variações, pelos efeitos das atividades desenvolvidas pela empresa"

Para Franco (1997, p.21):

A Contabilidade é a ciência que estuda os fenômenos ocorridos no patrimônio das entidades, mediante o registro, a classificação, a demonstração expositiva, a análise e a interpretação desses fatos, com o fim de oferecer informações e orientação - necessárias à tomada de decisões - sobre a composição do patrimônio, suas variações e o resultado econômico decorrente da gestão da riqueza patrimonial.

Segundo Szuster et al. (2013) a contabilidade, é um instrumento canalizado para gestão e controle das entidades. Sua finalidade é fornecer informações sobre os aspectos quantitativos e qualitativos do patrimônio da mesma. Já para Ribeiro (2013), o patrimônio das entidades é o objeto da contabilidade, e sua finalidade é a administração deste patrimônio a fim de prover informações consideráveis para seus usuários. Logo, pode-se dizer que a contabilidade é uma ciência que busca estudar, controlar e revelar, a realidade do patrimônio das organizações.

Para Viceconti e Neves (2013), a contabilidade possui uma estrutura própria, na qual tem a finalidade de: administrar o patrimônio das aziendas; conferir o crédito das atividades e prestar assistência às pessoas que tenham interesse, tanto na situação patrimonial como também na execução destas entidades.

Já Gonçalves e Baptista (2011), salienta que a finalidade da contabilidade é de arrolar os fatos ocorridos, produzindo assim informações perante o planejamento e controle das ações da empresa.

Lopes Sá diz que as finalidades da Contabilidade são: 
Orientação para investidores e para o mercado de capitais. Orientação para credores e instituições de crédito. Orientações sociais e trabalhistas. Análises científicas para modelos de comportamento da riqueza para ensejar decisões administrativas. Modelos para a prosperidade. Controles governamentais de fiscalização e auditoria fiscal. Instrumentos de provas judiciais e perícia contábil. Previsões de ocorrências e efeitos orçamentários. Explicação de fatos patrimoniais e análises contábeis. Investigação sobre a regularidade da gestão. Dados e pesquisa social e econômica. (SÁ, 1998, p. 89)

Para Crepaldi, os objetivos da contabilidade são:

Controlar o patrimônio da entidade; apurar o resultado das entidades; prestar informações sobre o patrimônio, sobre o resultado das entidades aos diversos usuários das informações contábeis. (Crepaldi,1995, p. 20).

Já para D’Amore os objetivos da contabilidade:

Dizem respeito à colaboração eficiente e constante que ela presta à administração econômica, no exercício de suas funções. (D’Amore, 1976, p. 21)

Portanto, o objetivo da contabilidade é guarnecer referencias reais sobre o patrimônio das pessoas e organizações, e sobre o resultado da entidade aos copiosos usuários das informações contábeis. Por estes olhos, vale frisar que, principalmente, a contabilidade busca em suas rotinas possibilitar suporte para que a administração possa tomar decisões baseadas em resoluções mais racionais para preservar e ampliar o patrimônio e, consequentemente, dar continuidade a entidade.

\subsection{Contabilidade Rural}

A contabilidade rural é uma ferramenta crucial nas tomadas de decisões, uma vez que tem grande potencial no que diz respeito aos benefícios financeiros e econômicos, ajudando inclusive a fazer novos investimentos, todavia, auxilia também na redução de custos e despesas, uma vez que a tecnologia e evolução vem crescendo diariamente, acarretando o crescimento da busca por melhores produtos e, com produtos de melhor qualidade o produtor precisa de técnicas para gerir sua empresa.

Segundo Crepaldi:

A Contabilidade Rural é o registro dos fatos ocorridos na atividade rural em 
determinado momento. Trata-se de uma escrituração contábil obrigatória, devendo ser contabilizadas mensalmente todas as receitas, os custos e as despesas, respeitando os princípios contábeis e as normas brasileiras de Contabilidade (Crepaldi, 2016, pg. 88).

O mesmo autor relatou sobre o propósito da contabilidade rural na qual esta pode ser usada para orientar a operação da agricultura e pecuária; medir e controlar o desempenho financeiro e econômico das empresas e diversas atividades produtivas; apoiar a tomada de decisão sobre a produção planejada, vendas e investimentos; auxiliar no caixa previsão de fluxo; permitir que outras empresas façam comparações em relação ao desempenho da empresa; ser responsável com as despesas tanto pessoais do proprietário da organização como da sua família; comprovar a liquidez e a capacidade de reembolsar os credores da organização; servir de fonte para seguros, leasing e bem como outros tipos de contratos e ofertar conjuntos de informações para o Imposto de Renda.

Ulrich (2009) relata a Contabilidade Rural como o ramo da contabilidade que se caracteriza pela aplicação às empresas rurais, visando mensurar e transmitir de forma clara os eventos e elementos relacionados as atividades e as transações inseridas executadas nas empresas. Oliveira e Oliveira (2017) define a Contabilidade Rural como um braço da Contabilidade aplicada, a qual emprega todos os seus conceitos e os métodos contábeis para determinar e mensurar corretamente um determinado patrimônio, bem como os seus resultados produtivos. Explicam também que a Contabilidade Rural destaca não apenas pelas práticas internas à propriedade, como atividade agrícola e zootécnica, mas também em seu lado externo como as indústrias de processamento, e demais organizações, as quais distribuem e vendem os produtos no varejo e atacado, sem se afastar de seus propósitos iniciais, que são de dar suporte para a mensuração e controle do patrimônio e apuração de resultados produtivos para responder à legislação fiscal.

Entretanto, esta forma de Contabilidade, na interpretação de Crepaldi (2016), apresenta envolvimento com a análise tanto do ativo, como do passivo e do patrimônio líquido das organizações, assumindo o compromisso de estruturar o negócio com determinados subgrupos, os quais encontram-se associados à atividade produtiva praticada. $O$ autor ainda descreve em seus estudos que a Contabilidade se apresenta ao dirigente como uma importante ferramenta gerencial, destacando informações que auxiliam na elaboração do planejamento, do controle e da tomada de decisão, fazendo 
com que o negócio rural seja lucrativo e com largo potencial de gerar riquezas.

Por esta visão, o poder de informar da Contabilidade Rural é observado por Crepaldi (2016) como ação de identificar o desempenho econômico e financeiro, os quais desempenham um papel importante para as análises e projeções dos fluxos de caixa, bem como possíveis necessidades de crédito. Estes conjuntos de estudos contábeis possibilitam para o dirigente das organizações comparar a performance da empresa, em um espaço de tempo, com outras organizações do mesmo segmento e tamanho, como forma de justificar a sua liquidez, para avaliação dos processos produtivos e dos investimentos demandados na realização destas atividades.

Oliveira e Oliveira (2017) observam que o ciclo operacional diferenciado revela uma variedade de produtos da atividade agropecuária e produção os quais são sazonais. São elementos que justificam fazer avaliação para ter certeza do melhor momento para apresentar as suas demonstrações contábeis. Para Marion (2014), o critério mais comumente aplicado é o ciclo operacional da cultura que apresenta maior representatividade econômica para a organização.

A Contabilidade Rural apresenta a sua atenção direcionada para o patrimônio e apuração dos resultados econômicos e financeiros da propriedade. Procura sempre aplicar os conceitos da Contabilidade Geral e apresentar, da melhor forma, os seus demonstrativos de resultados. Possui o cuidado de, através de levantamentos de informações e realização de cálculos específicos, divulgar relatórios que ofertem os números do desempenho da empresa e, desta maneira, contribuir para que os dirigentes dos empreendimentos rurais possam tomar as decisões de modo mais assertivo (OLIVEIRA; OLIVEIRA, 2017; MARION, 2014).

Ressaltando o nosso tema, Crepaldi cita que:

\begin{abstract}
A Contabilidade Rural é um dos principais sistemas de controle e informação das empresas rurais. Com base nos registros contábeis e na análise das demonstrações contábeis ou financeiras, é possível levantar a real situação financeira da empresa sob a ótica da análise de estrutura, de evolução do negócio, análise de solvência, retorno sobre o investimento etc. A informação contábil também pode ser utilizada no planejamento e controle para análise de redução de custos e despesas e para avaliação da necessidade de captação de recursos de terceiros. (CREPALDI, 2017, p. 89)
\end{abstract}

Adicionalmente, a Contabilidade Rural em suas ações e realizações, busca atuar em conformidade com as recomendações legais como as normas relativas à 
prática contábil do ativo biológico.

\section{$2.4 \quad$ Atividades Rurais}

O meio rural é encarregado pelo seguimento de inúmeras atividades na qual estas são divididas em produção agrícola, zootécnica e agroindustrial. Nepomuceno (2004) classifica como atividades rurais:

[...] a extração e a exploração vegetal e animal; a exploração da apicultura, avicultura, cunicultura, suinocultura, sericicultura, piscicultura e outras culturas animais; a transformação de produtos decorrentes da atividade rural, sem que sejam alteradas a composição e as características do produto in natura, feita pelo próprio agricultor ou criador, com equipamentos e utensílios usualmente empregados nas atividades rurais, utilizando exclusivamente matéria-prima produzida na área rural explorada; o cultivo de florestas que se destinem ao corte para comercialização, consumo ou industrialização. (NEPOMUCENO, 2004, p. 118).

Para Porto e Gonçalves (2011) independente da empresa rural pertencer ao empresário, é este que explora as atividades rurais. A empresa rural possui características próprias das demais empresas civis. As regras que devem ser seguidas na execução das atividades rurais devem seguir os devidos critérios como: cumprir os requisitos econômicos mínimos estipulados em lei, observar as relações de trabalhos justos e garantir o bem-estar dos empregados no empreendimento. Além desses fatores, os padrões de desempenho técnico e a garantia da proteção ambiental são amparados por meio de práticas protecionistas. As atividades rurais podem ser divididas em três categorias: atividades agrícolas (produção vegetal), atividades de tecnologia animal (produção animal) e atividades agroindustriais (indústrias rurais).

\subsubsection{Atividade Agrícola}

A atividade agrícola são diversas formas de se cultivar plantas alimentícias, matéria-prima, energia, estética entre outros. Marion classifica a atividade agrícola em dois grandes grupos (MARION, 2012, p. 2):

2.4.1.1 hortaliças (verduras, tomate, pimentão...); Culturas hortícolas e forrageiras:

2.4.1.1.1 Cereais (feijão, soja, arroz, milho, trigo, aveia...); 


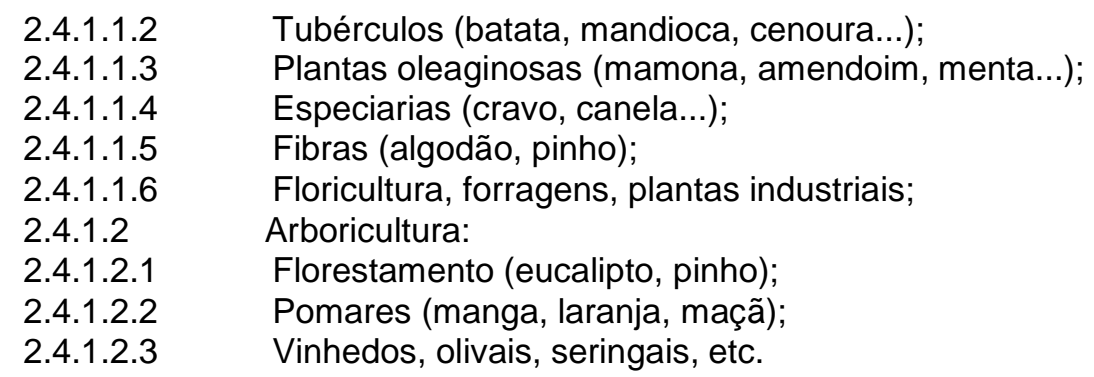

Segundo Francisco (2020), as atividades agrícolas estão sendo atualizadas para aumentar a produtividade, visando cada vez mais o sucesso agrícola, na década de 1950. Os ativistas rurais utilizavam tecnologias mais modernas, ou seja, disponibilizando em laboratório uma variedade de plantas geneticamente modificadas, espécies agrícolas desenvolvidas para atingir alta produtividade, uma série de utilização de técnicos e maquinários de processamento de agrotóxicos. Na década de 60 o programa desenvolvido recebeu o nome de Resolução Verde o qual foi financiada pelo Grupo Rockefeller. Esta tática visava aumentar a produção de alimentos para acabar com a fome no mundo além de fortalecer a corporação com vendas de verdadeiros pacotes de insumos agrícolas. $O$ autor acrescenta ainda que além da finalidade supracitada, outros benefícios surgiram como: desenvolvimento de pesquisas em sementes; fertilização do solo e a utilização de máquinas no campo que aumentassem a produtividade. Apesar de todo esse empreendimento, a Resolução Verde não extinguiu o problema da fome, porque a maior parte dos produtos eram exportados para países ricos industrializados. Nas atividades agrícolas, encontramos pontos positivos e negativos. Através dos pontos positivos surgirão: o aumento significativo da produtividade alimentar, surge o desenvolvimento da produção agrícola em países não industrializados, entre outros. Quanto aos pontos negativos temos: endividamento dos agricultores provocado pelo aumento de despesa; ausência da independência agrícola, provocando competitividade entre os países; enfraquecimento do solo produtivo; aumento de fertilizantes em série; ausência de variedade biológica; desgaste do solo, entre outros.

\subsubsection{Atividade Zootécnica}

De acordo com Freitas (2012) dentre as atividades de criação de animais no Brasil, a maior atividade animal é a pecuária, ou seja, o rebanho bovino, que está 
intimamente relacionada às atividades econômicas.

Entretanto, para Porto e Gonçalves (2011) as atividades zootécnicas são divididas em: Apicultura (apicultura); Avicultura (avicultura); Criação de coelhos (criação de coelhos); Pecuária (pecuária); e entre outros pequenos animais

\subsubsection{Atividade Agroindustrial}

De acordo com Porto e Gonçalves (2011) as atividades agroindustriais incluem o processamento de produtos agrícolas (arroz, café, milho etc.). O processamento de produtos pecuários em mel, laticínios, casulos de seda, entre outros. Com os produtos agrícolas serão obtidos: cana-de-açúcar em álcool; soja em óleo; uvas em vinho. Já para Freitas (2020), esse tipo de atividade realiza transformações em produtos primários para subprodutos tanto alimentícios (frigoríficos, enlatados, laticínios) como utilitários usados em várias áreas (couro, produção têxtil e outros). Portanto, a agroindústria pode ser definida como uma indústria que processa alimentos de origem animal e vegetal para obter produtos que atendam aos padrões de produção e qualidade. Como se pode observar na Figura 1.

Figura 1: Classificação das Atividades Rurais.



Fonte: Marion (2000) 


\subsection{Contabilidade Digital}

A contabilidade digital é utilizada para a prestação de serviços via internet, na qual este propõe a utilização do TI (Tecnologia da Informação) para estruturar a escrituração e a demonstração, beneficiando o contador. Através deste tipo de contabilidade as informações são fiscalizadas pelos órgãos competentes e em virtude da organização dessa atividade as fraudes e as sonegações tornam-se quase nulas (Soares, 2019). A autora ainda salienta que a contabilidade digital representa a inovação dos serviços contábeis quesão executados via internet e de softwares online. Através destas ferramentas é possível a inclusão dos profissionais contábeis com seus compradores e fornecedores. A autora ainda ressalta a contabilidade digital é efetuado de forma compartilhada por clientes e contadores onde ambos desfrutam de benefícios, como lucro de produtividade, contenção de custos e maior segurança. $\mathrm{Na}$ contabilidade digital, as informações contábeis estão disponíveis em um sistema de gestão, onde os documentos são enviados de forma digitalizada, tornando assim possível a diminuição dos erros ocorridos nos escritórios. Soares (2019) enfatiza que é fundamental o conhecimento na contabilidade digital, principalmente para os contabilistas, pois quando os supracitados agregam a tecnologia à sua profissão, as tarefas executadas tornam-se mais eficientes. Este tipo de contabilidade se manifestou aqui no Brasil em 2015, trazendo com ela uma inovação para os contabilistas. Com o uso da internet e da tecnologia surgiram ferramentas para aperfeiçoar e beneficiar melhor os serviços dos profissionais contábeis.

Com a contabilidade digital, os escritórios passaram a ganhar vantagens nos atendimentos com seus clientes, favorecendo o acesso direto das informações necessárias, sendo possível ainda efetuarem de maneira mais rápida nas partes burocráticas, além de ganhar mais tempo para o acompanhamento de gestão dos seus clientes. Enquanto a parte atuante do escritório fica para a tecnologia, o gestor consegue oferece aos seus clientes serviços mais especializados, tornando possível o contador agregar valor ao seu escritório contábil (Soares, 2019).

Já para Corrêa (2018) a contabilidade digital por ser nova no mercado, tornouse popular no desempenho de suas atividades, isto é, através do sistema ERP.

Para que uma empresa adquira um sistema de informação integrado é necessário o uso do sistema ERP, tendo este a finalidade de oferecer o suporte a maioria das informações. Este sistema é dividido em módulos, os quais tanto se 
comunicam como se atualizam em uma única base central. Através deste sistema é permitido a utilização de ferramentas de planejamento como: manufatura, suprimentos, finanças, recursos etc... Este sistema possui várias características que quando agrupadas se distinguem dos sistemas internos nas organizações e de outros tipos de pacotes comerciais. Algumas dessas características são fundamentais para a compreensão de alguns benefícios e dificuldades, sendo estas relacionadas com a sua aplicação (SOUZA, 2008).

De acordo com Schultz (2020) o objetivo da contabilidade digital no momento atual é suprir algumas necessidades como a agilidade no processo, a segurança nas informações além de uma comunicação rápida. Com a era da informatização, surgiu a aproximação das pessoas e com isso ocorreu a redução da distância.

O autor ainda ressalta que a contabilidade digital tem como principais objetivos:

a) Agilidade na execução dos serviços referentes ao escritório contábil;

b) Melhoraria na comunicação;

c) Integrar valores;

d) Atender aos regimes tributários de forma fácil;

e) Salientar na excelência e na qualidade das atividades executadas e;

f) Eliminação de obstáculos, como o distanciamento.

A Contabilidade Digital funciona sem a utilização de malotes, facilitando para os contabilistas a visualização dos dados e das informações das empresas tendo, portanto, uma plataforma de livre acesso. Segundo Schultz (2020) este tipo de contabilidade integra os contabilistas e os clientes mediante um único sistema de gestão como: financeiro, controle de estoque entre outros.

Com o avanço da tecnologia surgiram vários benefícios para os indivíduos como para as empresas que utilizam da supracitada tonando assim possível a otimização de seus serviços trazendo assim vantagens tanto para a empresa como para os profissionais da área. Para Marinho (2019) definir a contabilidade digital não basta para ter conhecimento, é importante que os usuários deste tipo de contabilidade conheçam suas vantagens e como ela pode contribuir com a empresa.

Para Schultz (2020) as principais vantagens para as empresas como para os profissionais da área são: produtividade, redução de custos, otimização de tempo, 
entre outros.

\subsection{Comissão de Normalização Contabilística 29}

O segmento da Contabilidade Rural, como qualquer outro setor de atividade produtiva, apresenta em suas rotinas dificuldades e riscos os quais são particulares, pois contempla fatores e caminhos operacionais específicos, como o impacto dos elementos climáticos ou das modificações biológicas (desenvolvimento, produtividade, reprodução entre outros) que interferem e alteram constantemente a substância do ativo biológico, implicando na conveniência da utilização deste princípio no custo da organização ao apurado ao longo do tempo (ALVES; PASCOAL, 2017).

O International Accounting Standards Board (IASB), ao reconhecer essas instabilidades dos processos produtivos rurais, editou a norma IAS 41, no ano 2000, sendo a primeira norma específica e direcionada ao setor agrícola publicado pelo IASB. Esta norma estabeleceu os modos de medir e de identificar os ativos biológicos por um valor adequado. Por essa determinação, passou a oferecer às empresas dados informativos confiáveis, que possibilitam uma melhora na qualidade da informação no processo de tomada de decisão dos dirigentes nas organizações rurais (ALVES; PASCOAL, 2017).

Em seguida, a Comissão de Normalização Contabilística (CNC) instituiu o Sistema de Normalização Contabilística (SNC), que historicamente fez parte da Norma Contabilística e de Relato Financeiro (NCRF) 17, norma que apresenta como base a IAS 41 e, por isso, relata similares ordenamentos. A NCRF 17 original indicada pelo Aviso n. 15.655/2009 foi atualizada pelo Aviso n. 8.256/2015 (ALVES; PASCOAL, 2017). Por este comportamento, no Brasil, a Contabilidade convergiu aos padrões internacionais de forma legal ao ser determinada a regulamentação das Leis $n^{\circ}$ 11.638/07 e nº 11.941/09. Essas leis, de acordo com seus conteúdos, apresentaram algumas mudanças na Lei das Sociedades por Ações, Lei nº 6.404/76 (AMARO; SOUZA; SILVA, 2016).

Ao prever que modificações significativas estavam por acontecer na forma como as práticas contábeis eram empreendidas, em 2005 foi criado o CPC (Comitê de Pronunciamento Contábeis), que possuía o objetivo de pesquisar, desenvolver e ofertar por meio de documentos como os de documentação técnica, os caminhos 
metodológicos da contabilidade, considerando-os sempre em convergência e cotejamento com a contabilidade brasileira e aos padrões internacionais (CPC 29, 2013).

Neste período foi possível perceber que ocorreu uma alteração relevante nos procedimentos de reconhecimentos e suas métricas do exercício contábil realizado no Brasil a partir da entrada em vigor do CPC 29 de Ativo Biológico e Produto Agrícola. Essas inovações levaram a Contabilidade do Agronegócio a implementar suas reformas. Com essas alterações, uma das novidades instituídas, mais relevante, foi a contabilização dos ativos biológicos que passou a ter os lançamentos considerando um valor adequado, de acordo com a determinação do Pronunciamento Técnico CPC 29, divulgado em 2009, sendo adotado pelas empresas brasileiras a partir de 2010 (YOSHITAKE; TINOCO; FRAGA, 2014).

O CPC 29 apresenta na configuração de seu conteúdo buscando definir as orientações para a prática contábil do agronegócio. Dessa forma, "o objetivo deste pronunciamento é estabelecer o tratamento contábil, e as respectivas divulgações, relacionados aos ativos biológicos e aos produtos agrícolas" (CPC 29, 2013, p. 697). Este pronunciamento foi instituído no sentido de ser aplicado no tratamento contábil dos itens pertencentes às atividades agrícolas, tais como: ativos biológicos menos as plantas portadoras; volume produtivo agropecuário no momento de sua colheita e destinação para o abate; e subvenções governamentais expostas no texto. Entretanto, não apresenta aplicação para os casos de: terras associadas com atividades agrícolas; cultivos relacionados com a produção agrícola; subvenção e apoio do governo para as plantas portadoras; e ativos intangíveis que tenham ligação com atividades agrícolas. Enfatiza também, que deve ser aplicado na contabilização da produção agrícola, considerando seu estado no mesmo instante que estiver colhendo os produtos originados dos ativos biológicos da propriedade (YOSHITAKE; TINOCO; FRAGA, 2014).

Portanto, o ordenamento do CPC 29 é claro quanto à maneira de efetuar a contabilização dos ativos biológicos e produtos agrícolas. Ressalta-se que 0 ato contábil deve configurar os procedimentos adequados para o tratamento dos itens especificados na norma, mesmo em sua complexidade de interpretação. É a maneira de realizar a contabilidade da propriedade rural dentro das recomendações legais e pronunciamentos indicados pela norma (CPC 29, 2013). 


\subsubsection{Ativos Biológicos e Produtos Agrícolas}

O CPC 29, nas definições pertinentes com a produção agropecuária, estabelece alguns significados os quais estão presentes no Pronunciamento com termos específicos. Desta forma: "Ativo biológico é um animal e/ou uma planta, vivos" e "Produção agrícola é o produto colhido de ativo biológico da entidade" (CPC 29, 2013, p. 697).

Cardoso e Silveira (2017) explicam que ativo biológico integrante da atividade agrícola é planta ou animal envolvido no processo de transformação biológica (desenvolvimento, decrepitude, produção e procriação, as quais implicam alterações no ativo biológico nas ordens quantitativas e qualitativas) e da colheita de ativos biológicos para comercialização, transformação em produtos agrícolas (ou seja, o produto colhido ou conseguido pelo ativo biológico da empresa) ou em ativos biológicos agregados à instituição, desde que não se configure como uma planta portadora. Os autores também descrevem que o produto agrícola integra o subgrupo estoque e apenas na sua avaliação inicial (nascimento ou colheita) é que seu tratamento equivale aos ativos biológicos, isto é, mensurado pelo valor justo. O reconhecimento do produto agrícola no subgrupo estoque pode ser caracterizado por ser ele mesmo a mercadoria para revenda ou como matéria-prima de outros produtos. Em seus estudos Zanin et al. (2015) observaram que o Pronunciamento CPC 29 (2013) apresenta exemplos de ativos biológicos, produtos agrícolas e também os resultados da transformação os quais podem ser observados no Quadro 1. 
Quadro 1 - Exemplos de Ativos Biológicos, Produtos Agrícolas e seus resultados depois do processamento.

\begin{tabular}{|c|c|c|}
\hline Ativos biológicos & Produto agrícola & $\begin{array}{c}\text { Produtos resultantes do } \\
\text { processamento depois da } \\
\text { colheita }\end{array}$ \\
\hline Carneiro & Lã Fio, tapete. \\
\hline Árvores de uma Plantação & Madeira & Madeira serrada, celulose. \\
\hline Plantas & Algodão & $\begin{array}{c}\text { Fio de algodão, roupa Açúcar e álcool } \\
\text { Café limpo em grão, moído e torrado. }\end{array}$ \\
\hline Gado de leite & Leite & Sueijo. \\
\hline Porcos & Carcaça & Chácha, presunto. tabaco. \\
\hline Arbustos & Folhas & Vinho. \\
\hline Videiras & Uva & Fruta processada. \\
\hline Árvores frutíferas & Fruta colhida & \\
\hline
\end{tabular}

Fonte: Zanin et al (2015) apud CPC 29 (2013).

Ativo biológico, de acordo como CPC 29, é caracterizado com um ativo vivo e, por este aspecto, todo vegetal ou animal empregado diretamente nos processos produtivos pode satisfazer esse critério. O principal aspecto que difere os ativos biológicos dos outros decorre do evento que sofrem alterações no transcorrer do tempo, sendo essas transformações de ordem tanto qualitativas (ex. desenvolvimento de plantas), como quantitativas (ex. ganho de peso do gado). Esse processo é denominado pela norma como "mudança biológica" (CPC 29, 2013).

Destaca-se que os ativos biológicos são passíveis de contrair características variadas ao longo de sua vida em função das alterações biológicas. Certas culturas demandam um determinado tempo para alcançar o ponto de maturação, outras necessitam de um tempo mais longo para o seu crescimento. Algumas precisam de elevados níveis de investimentos e reparos, outras nem tanto. São fatores que refletem em números contábeis específicos para sujeitos externos a produção rural, ou também não apresentam com fidedignidade o vigente cenário produtivo da organização. Uma demonstração prática é possível de ser vista quando certos ativos biológicos de amplo período para o seu amadurecimento, são observados no resultado depois de um longo tempo, outros mais imediatos para amadurecer e refletir o resultado de maneira mais oportuna. Todos esses produtos obtidos a partir desses 
ativos são identificados como produtos agrícolas (PRATA; NOGUEIRA, 2017).

$O$ ativo biológico e o produto agrícola são objetos de destaques no pronunciamento CPC 29 que procura estabelecer os procedimentos adequados para realização do tratamento contábil. Essa norma foi promulgada com o propósito de regulamentar a tratativa a ser empreendida para o ativo biológico e o produto agrícola, estabelecendo uma relação com as determinações internacionais de Contabilidade IAS 41. O CPC 29 descreve os tratamentos contábeis por meio dos critérios de reconhecimento, mensuração e evidenciação (PRATA; NOGUEIRA, 2017).

\subsubsection{As controvérsias entre o Custo Histórico e o Valor Justo}

O estudo de ativos se apresenta como um dos alicerces da contabilidade e a sua mensuração e revelação dos custos historicamente constituídos foi fonte de avaliação utilizada pelos gestores (LUDíCIBUS, 2008). Com grande parte convergente das ferramentas da contabilidade, os ativos das empresas pequenas e médias necessitam de uma avaliação justa.

Segundo Barros et al. (2012), antes do CPC 29, a mensuração dos ativos biológicos era ofertada pela NBC-T 10.14 (entidade agrícola). A agência avaliou esses ativos pelo valor original ou custo histórico, confirmando assim o Lucro só pode ser perdido ao comprar ou vender. Por meio do CPC 29 obrigatório, os ativos biológicos passaram a ser registrados para cada uma das demonstrações financeiras pela busca do valor justo subtraído os custos das vendas, que ajustará diretamente o resultado do exercício corrente.

Rech et al. (2006) salienta que sob a permissão do IAS 41, o modelo contábil introduziu um método para avaliação e confirmação do valor justo dos ativos biológicos. No entanto, Holtz e Almeida (2013) argumentam que as discussões sobre o uso do valor justo na contabilidade nem sempre produzem visões semelhantes. Rech (2011) relatou que a empresa não faz a utilização dos padrões e divulga informações incompletas sobre os ativos biológicos.

A mudança no método de determinar o ativo biológico passando pelo emprego do seu custo historicamente constituído para valor justo motivou na discussão de Rech e Pereira (2012), que salientam que o custo histórico antes utilizado era mais objetivo e de fácil verificação, diferente do valor justo que é mais interessante para as tomadas de decisão. 
Em relação aos produtores rurais entrevistados, eles desconhecem o uso de ferramentas na tomada de decisão. $\mathrm{Na}$ análise dos principais serviços contábeis utilizados, encontramos serviços que possuem obrigações tributárias, tais como: folha de pagamento de empregados imobiliários, imposto de renda (IR), imposto territorial rural (ITR) e certificado de registro de propriedade rural (CCIR). Vale ressaltar que é justamente pela falta de conhecimento e informação que os produtores rurais colocam em segundo plano a gestão. No entanto, a contabilidade rural geralmente é usada apenas para cumprir as leis e o estado. Essa realidade mostra que os produtores rurais não sabem muito sobre os benefícios da contabilidade rural e como administrar seus negócios de forma eficaz.

Segundo Sputitz, Wobeto e Hofer (2008), a contabilidade rural possui ferramentas que colaboram na tomada de decisões, embora sejam precariamente utilizadas nas atividades rurais. Para que a contabilidade seja disseminada na atividade rural é preciso, que as atividades propostas sejam inseridas pelos profissionais da área contábil.

Para Marion (2001, p.39) o contador:

\begin{abstract}
Deve desempenhar aqui um papel importante nas negociações interregionais, assessorando, pesquisando, trazendo informações e elementos que assegurem o fluxo de informação contínua, que leva a uma tomada de decisão racional, devendo oferecer um serviço socialmente útil e profissionalmente eficiente, que não seja apenas fruto da experiência e da formação universitária recebida, mas também de seu compromisso de incrementar e renovar constantemente o caudal de seus conhecimentos em prol da unidade regional.( MARION, 2001, p. 39).
\end{abstract}

Já Crepaldi (2006), além de tornar públicos os planos e avaliações para monitorar o andamento das atividades, os gestores devem sempre focar nas tarefas de planejar, organizar, dirigir e exercer o controle administrativo. Portanto, a contratação de oficiais técnicos para gerenciar a contabilidade exige que os agricultores tenham um entendimento abrangente de suas atividades e determinem metas para que essas informações possam ser repassadas para a equipe de contabilidade e o processo de registro da transação seja explicado com detalhes em conjunto.

Portanto, conclui-se que as pequenas e médias empresas rurais devem ser administradas de forma eficaz, sendo a contabilidade rural a ferramenta básica dessa 
gestão, pois os métodos acima auxiliam: o planejamento, desenvolvimento, controle e nos ajustes necessários para fornecer informações para que o produtor rural decida da melhor maneira.

\subsubsection{Ativos biológicos: reconhecimento}

Em função das normas estabelecidas para a contabilização no agronegócio, pode-se perceber no Brasil uma alteração relevante nos procedimentos para atratativa contábil dos ativos biológicos e produtos agrícolas. Diante das modificações, a Contabilidade Rural aderiu às novas orientações. Uma inovação significativa do CPC 29 foi contabilizar os ativos biológicos, de forma prioritária, com base no valor justo (NOGUEIRA; PIRES, 2017).

O Pronunciamento CPC 29 orienta que a tratativa contábil deve enfatizar o entendimento do que seja um ativo biológico ou produto agrícola em determinadas circunstâncias (CPC 29, 2013), como:

a) quando delimita o domínio do ativo como resultado de acontecimentos antecedentes;

b) quando for expressa a probabilidade dos ganhos econômicos a serem alcançados, relacionados com o ativo seguirem para a empresa; $\mathrm{e}$

c) quando o valor justo ou o custo do ativo revelar condições de serem medidos de forma segura e fidedigna com a realidade mercadológica do momento.

Para Padoveze, Benedicto e Leite (2012, p.396), a empresa só deve confirmar os ativos biológicos nas seguintes circunstâncias:

a) Os ativos são controlados por eventos passados (exemplo de controle:quando os ativos biológicos têm titularidade legal);

b) Pode gerar benefícios econômicos futuros; e

c) O valor justo ou custo dos ativos pode ser mensurado com segurança.

Satisfeitos todos estes critérios, a empresa pode registrar o ativo, porém pelo 
não atendimento de qualquer um destes parâmetros, o ativo biológico presente nas propriedades rurais não poderá ser empregado na sua prática contábil. Ao ser feita uma avaliação minuciosa, pode-se perceber que na realidade estes critérios provêm das determinações básicas para qualquer ativo de uma organização. Desta forma, caso a organização não possua o controle do ativo nem do histórico plausível que mostre o acompanhamento do ativo, a instituição não pode identificá-lo. Assim, se o ativo não produzir incremento desejado no ato de projeção de um tempo futuro, não poderá ser reconhecido como um ativo, não podendo ser medido também não podendo ser demonstrado (NOGUEIRA; PIRES, 2017).

Reconhecimento é o processo que faz a formalização nas organizações de um certo elemento do processo produtivo nas demonstrações financeiras de uma empresa como um ativo, passivo, receita ou despesa, fazendo a apresentação tanto em números quanto em palavras (AMARO; SOUZA; SILVA, 2016). O reconhecimento contempla tanto a avaliação inicial de um item quanto o que se pode observar pelas mudanças posteriores ou em remoção de um item reconhecido previamente (NIYAMA; SILVA, 2013).

Portanto, o reconhecimento é um procedimento recomendado pelo CPC 29 para realização do tratamento contábil dos ativos biológicos e produtos agrícolas de propriedade de uma determinada entidade, observando se os benefícios econômicos e futuros que possam produzir vão fluir para a empresa e seu custo ou valor tenham condições de seres identificados e mensurados com segurança.

\subsubsection{Ativos biológicos: mensuração}

A mensuração dos ativos biológicos desempenha um papel importante na determinação do patrimônio líquido da empresa e na determinação do resultado (lucro e prejuízo) do período. Diferentes resultados podem ser obtidos a partir do método de

mensuração utilizado, do valor dos ativos biológicos apresentado no balanço patrimonial e do resultado apurado na demonstração do resultado do exercício (DRE).

Considerando que o prazo de validade do "CPC 29-Ativos Biológicos e Produtos Agrícolas" no Brasil é muito curto, e as pesquisas sobre mensuração de ativos biológicos ainda estão engatinhando. Esse tipo de comunicado emitido pelo Comitê de Divulgação Contábil (CPC) afirma que "no momento do reconhecimento inicial e ao final de cada período de apuração, o ativo biológico deve ser mensurado 
ao valor justo menos as despesas com vendas". (CPC 29, p. 6). No entanto, este só permite que o método do custo seja usado em circunstâncias especiais, nas quais o valor justo não pode ser mensurado com segurança.

Quando um ativo biológico atende a todos os parâmetros para a sua determinação, é preciso que seja determinado para constar nas demonstrações financeiras. Assim, conforme a CPC 29 (2013, p. 14) cita que a sua aferição se realize "pelo valor justo menos a despesa de venda no momento inicial e no final de cada período de competência".

Um dos grandes desafios para os avaliadores dos ativos biológicos é determinar o valor justo para o produto avaliado como ativo, para o CPC 29, é o preço a ser recebido pela sua venda ou a ser pago por um passivo por meio da sua transferência em uma negociação voluntária, entre atores do mercado no momento da sua quantificação (CPC 29, 2013).

Desta forma, o valor justo é o que se pode obter em um mercado consumidor em que existe um valor o qual a empresa concorda disponibilizar o seu ativo e outra empresa aceita adquiri-lo pelo valor em destaque. Caso se constate um mercado consumidor aquecido em demanda, deve- se considerar a localização da organização e do seu ativo biológico no momento da determinação do seu valor. Logo, o preço usado na análise neste tipo de mercado consumidor é o parâmetro para definir o valor justo do ativo biológico. Porém, se a empresa pode acessar mais de um mercado (dois centros em que possa negociar os ativos biológicos), neste caso, a ela é importante que utilize o valor trabalhado no lugar em que possui a intenção de negociá-lo (NOGUEIRA; PIRES, 2017).

$\mathrm{O}$ ativo biológico, em determinado momento, pode ser mensurado de modo seguro por um valor justo, a organização deve utilizá-lo como fator de mensuração. Há de ser destacado que a orientação apresentada pelo pronunciamento, de que existem situações em que o valor justo não é possível de ser determinado, relacionado ao ciclo de vida do ativo, apenas pode possuir validade no momento primeiro em que ocorre reconhecimento do ativo biológico. Uma vez que o ativo biológico foi quantificado pelo valor justo, deve-se seguir utilizando o mesmo parâmetro de métrica até disponibilizá-lo a sua oferta ao mercado como ativo para o mesmo. (CPC 29, 2013).

Para Padoveze, Benedicto e Leite (2012, p. 396) ressaltam que os principais 
critérios de mensuração são:

a) A menos que os ativos biológicos não possam ser determinados de maneira segura, eles devem ser revelados ao valor justo no momento da sua identificação inicial e na data de cada balanço menos o custo estimado no momento da venda.

b) Os produtos agrícolas colhidos dos ativos biológicos da empresa devem ser determinados o seu valor justo menos o custo estimado das vendas no momento da colheita.

c) Os custos do local de venda do produto somam as comissões cobradas de corretores e sujeitos que negociaram, taxas de reguladores e bolsas de mercadorias e taxas de transferência e tarifas.

d) Ao agrupar ativos biológicos ou produtos agrícolas a partir dos seus atributos importantes, o valor justo dos ativos biológicos ou produtos agrícolas podem ser facilmente determinados.

De acordo com o CPC 46, a mensuração do valor justo possui uma estrutura hierárquica do maior (nível 1) ao menor (nível 3), que possui três condições: no primeiro nível, os preços em mercados ativos são listados para o mesmo commodities; no segundo nível, os preços de commodities semelhantes são cotados, e não há mercado para essas commodities e o terceiro nível é usado apenas sem o primeiro e o segundo níveis, ele terá dados não observáveis, esses dados refletem A premissa de participação de ativos e passivos, ou seja, reconhece que há pouca ou nenhuma atividade no mercado ativo ou passivo naquele dia e a medição requer tecnologia de avaliação.

Sendo assim, a mensuração requer de três níveis, ou seja, quanto maior o nível maior a subjetividade da medição, portanto, o nível 3 tem maior subjetividade do que os outros níveis, pois considerando essas técnicas de avaliação, isso significa que há uma maior possibilidade de desvios e erros de medição, da mesma forma queo fluxo de caixa descontado, requerem a definição da taxa de desconto e do período durante o qual o fluxo de caixa relacionado ao elemento medido flui para a empresa. (SILVA FILHO; MARTINS; MACHADO, 2013). 


\subsubsection{Ativos biológicos: evidenciação}

Segundo ludícibus (2010), a evidenciação está relacionada ao objetivo da contabilidade, uma vez que este objetivo relatar informações que a maioria dos usuários pode usar de forma flexível. Portanto, é uma oportunidade adequada para fazer essa divulgação com informações claras, confiáveis e com a qualidade estabelecida pelo pronunciamento conceitual básica.

Hendriksen e Van Breda (1999) relatam que no que se refere à divulgação como portadora de informações, seguindo os conceitos de suficiência, justiça e completude, ela deve seguir padrões ideais. Visto que a divulgação adequada é projetada para evitar declarações financeiras enganosas, a divulgação justa fornecerá um tratamento ético e justo a todos os leitores em potencial. Portanto, divulgação completa significa fornecer informações relevantes. Para Cordeiro (2003), evidenciase as informações divulgadas pela empresa para auxiliar os analistas no entendimento das condições financeiras, econômicas e sociais da empresa. Niyama (2013) enfatizou que a contabilidade é a linguagem da comunicação empresarial, e a evidenciação é uma excelente ferramenta. $O$ autor ressaltou ainda que esta evidenciação como uma tradução clara para os usuários.

Entretanto, o CPC 29 estabelece que a comprovação da informação contábil a respeito do ativo biológico, busca ser divulgada em documentos explicativos, as notas, e que também seja publicada por meio de dados e informações que estabeleçam alguns parâmetros como: o ganho ou perda derivada da alteração no valor adequado, a determinação de cada conjunto de ativo biológico; difundir por meio e formato adequados como ocorreu a quantificação dos ativos; a presença de subvenções governamentais, entre outros pontos (CPC 29, 2013).

Para Ludícibus (2010), a evidenciação está diretamente relacionada aos fins contábeis, sendo as áreas acima citadas violadas por importância e relevância. Ainda de acordo com o autor, embora esta evidenciação leve a coleção de demonstrações financeiras como atributos, ela pode ser implementada de várias maneiras:

a) As informações entre colchetes: utilizadas como complemento às demonstrações financeiras, com breve descrição do título e subtítulo;

b) Nota explicativa: Utilizados como principal método de divulgação no Brasil, 
devem incluir elementos relacionados ao patrimônio líquido, estoque, depreciação, amortização, consumo, critérios de avaliação de reservas para créditos de liquidação duvidosa, investimento em outras empresas e critérios de avaliação do valor adicionado. de ativos de informação, taxas de juros, stock options, quantidade, tipo e categoria de patrimônio, etc., ou outras informações relacionadas, desde que não haja excesso de custo que possa fazer os usuários entenderem;

c) Tabela complementar: podem ser apresentadas as informações detalhadas dos itens que aparecem no relatório, mas não se aplica ao seu corpo principal. Às vezes, no Brasil, as tabelas complementares são incluídas nas notas explicativas;

d) Opinião ou opinião do auditor: Trata-se de uma dupla divulgação, devendo ser utilizada a influência relevante dos métodos contabilísticos para proporcionar segurança aos utilizadores;

e) Relatório da administração: É uma forma de comunicação entre a alta administração e os usuários, geralmente contendo informações não financeiras, como plano de crescimento da empresa, despesas com pesquisa e desenvolvimento, entre outras informações que possam ser consideradas pendentes. 


\section{AS TECNOLOGIAS DA INFORMAÇÃO E COMUNICAÇÃO (TIC) NA PRODUÇÃO AGROPECUÁRIA}

Em tempos de pandemia da Covid-19 o desenvolvimento de tecnologias da informação para os empreendimentos agropecuários se tornou uma estratégia prioritária. A construção de caminhos comunicacionais remotos entre os agentes de uma cadeia produtiva agroalimentar, visando as suas mais variadas formas de interações em busca da manutenção da continuidade dos fluxos produtivos das cadeias agroalimentares, como a continuidade da frequência das entregados, custos de produção, padrões de qualidade, valor dos produtos, entre outros fatores garantidores da segurança alimentar e nutricional da população. A coordenação remota, via internet, por meio de aplicativos e outros tipos de programas internacionais, tenta garantir a manutenção da saúde de todos os sujeitos, pois auxilia no distanciamento social preconizado neste momento de pandemia.

De acordo com Neto, Pinto e Coelho (2005), as tecnologias da informação e comunicação (TIC) estão cada vez mais desempenhando um papel fundamental nas organizações empresariais, possibilitando assim a utilização das tecnologias da informação e comunicação para racionalizar custos e atingir níveis de desempenho mais elevados. Em termos de componentes de comunicação, o melhor aproveitamento das telecomunicações móveis, redes de contatos e fóruns de discussão pode ser muito importante, o que, no caso de uma concorrência cada vez mais acirrada, ajudará a melhorar a vantagem competitiva.

Atualmente, há uma oferta ampla de aplicativos que procuram auxiliar as mais variadas etapas dos processos produtivos que envolvem as etapas produtivas agropecuárias nos empreendimentos rurais. Eles costumam medir de forma pontual os vários aspectos produtivos, coletam dados e informações, e por meio de processamentos e análises ofertam um rol de possibilidades de soluções, amplas ou pontuais para o problema enfrentado ou na melhora dos processos produtivos. $O$ dado transformado em informação é usado pelo produtor nos seus processos de tomada de decisão, nos quais os principais objetivos seriam diminuir os custos de produção eo cuidado em manter os padrões de qualidade, que no caso de uma lavoura do tipo commodite, um dos seus elementos de controle seria a eliminação de pragas agrícolas. Historicamente, a produção de produtos commodities como a sucroalcooleira foi a precursora no brasil do emprego da Tecnologias Digitais de 
Informação e Comunicação (TDICs) em larga escala em suas rotinas produtivas (Ferraz; Pinho, 2017).

De forma mais pormenorizada, Vieira (2019) destaca que:

\begin{abstract}
O segmento agrícola tem adotado paulatinamente novos processos de préprodução, produção e pós-produção de alimentos que o habilitam a desenvolver e simular modelos de fenômenos complexos tanto na cultura de plantas quanto na produção animal e, especialmente, naquilo que tange as variabilidades climáticas, sanitárias, organolépticas, mercadológicas e, ainda, naquelas situações relacionadas à gestão da mão de obra. Fazem parte dessa mudança de paradigma as tecnologias relacionadas à Inteligência Artificial, à Internet das Coisas (loT), às plataformas de computação na nuvem ou à Bioinformática. $O$ que se observa no campo é um novo cenário que combina análise de dados, hardware, software e ferramentas de produção digitais que realizam a coleta, o armazenamento, a troca, o processamento e o manejo de todo tipo de informação e conhecimento rural(p.126).
\end{abstract}

Segundo Gelb e Voet (2009), ao utilizar as TIC (Tecnologia da Informação e Comunicação), além de trazerem uma série de benefícios agrícolas e econômicos, também podem aumentar a produtividade, como melhor produção e gestão da propriedade rural; disseminar informações departamentais importantes, melhorar planeja, acompanha a produção integrada e obtém os últimos resultados das pesquisas na área.

Já Goyal e Gonzáles-Velosa (2012) complementaram a lista de benefícios esperados usando as TICs em áreas rurais, mostrando que podem desempenhar um papel em:

a) Reduzir os custos de comunicação entre os intermediários (por exemplo, custos de comunicação relacionados ao uso de telefones celulares e ferramentas de Internet).

b) Reduzir o custo de obtenção de serviços (como seguros e crédito) e informações (mercado ou tecnologia).

c) Por meio de sistemas acessíveis de monitoramento e informação, os riscos relacionados a eventos climáticos, pragas e desastres naturais podem ser reduzidos.

d) Expandir a renda, melhorar a qualidade e atender às necessidades dos consumidores agrícolas.

Gregolin (2017) descreve em seus trabalhos que historicamente que os caminhos percorridos para se levar as informações ao campo eram utilizados o rádio, 
televisão, jornais, revistas entre outros. O autor ressalta que esses meios de comunicação de massa são pouco dialógicos. Não permitindo uma interação maior do interlocutor, que se encontrava nos territórios rurais. Entretanto, ressalta que nas últimas duas décadas com o advento da internet, ocorreu também uma mudança nas interações no campo, criando uma variedade de possibilidade dessas interações serem mais dialógicas, com uma comunicação bidirecional e não hierárquicas.

O autor ainda observa que na atualidade:

\begin{abstract}
"estes meios de comunicação estão rodeados de outros meios pelos quais a troca de mensagens é dinamizada. Com o advento e popularização do computador e da internet criou-se um campo fértil para a proliferação de aplicativos os quais tentem a facilitar o cotidiano dos habitantes, sejam eles rurais ou urbanos. Redes sociais e aplicativos de mensagens instantâneas são utilizados nas ATERS bem como aplicativos específicos, feitos sob medida para atender o público da agricultora e prometem uma revolução no campo a partir da sua utilização. (p. 74)
\end{abstract}

Com o surgimento das Tecnologias Digitais de Informação e Comunicação (TDICs) as fronteiras dos significados, que definiam muitas vezes de forma superficial, o que seriam os espaços urbanos dos rurais, se tornaram mais permeáveis.

Bernardes era al. (2017) relatam em seus estudos que:

Desse modo, o processo conceitual promovido envolve relações nas esferas históricas, geográficas, socioeconômicas e culturais que se apresentam intrínsecas ao desdobramento da relação campo cidade e têm passado por um conjunto de mudanças com impactos significativos nas relações apontadas. (p.142)

Para os autores as profundidades e amplitudes das interações dialógicas entre os sujeitos, por meio dos caminhos comunicacionais, cada vez mais presentes e intensos das TDICs, aproximam as mais variadas formas de interações entre os sujeitos, que moram e trabalham nos territórios rurais e urbanos. E preconizam o desenvolvimento de posturas dialógicas entre os sujeitos que moram, vivem e trabalham nesses dois locais, por meio de caminhos comunicacionais proporcionados pelas TDICs. E ainda ressaltam que:

Para tanto, torna-se fundamental tanto o acesso técnico às TICs, na perspectiva de sinal, rede elétrica, capacidade aquisitiva, quanto ao desenvolvimento de competências para que a inclusão digital possa ser um elemento concreto para a redução das desigualdades entre zona urbana e rural e de integração cultural, social e econômica. (p.151) 
As relações monológicas e dialógicas que permeiam esses novos caminhos comunicacionais advindos das TDICs vão definir como serão as relações futuras, não apenas aquelas relacionadas as rotinas produtivas, mas também outros aspectos. Um dos gargalos para a sua massificação nos territórios é justamente o acesso a internet. Dados do censo agropecuário de 2017 evidenciam que 71,8\% das propriedades agrícolas brasileiras não possuem acesso a internet. Apensar de apresentar um crescimento expressivo da oferta desse serviço encontrado nesse último levantamento (IBGE, 2017).

De acordo Mendes, Buainain e Fasiaben (2014) há uma concentração destes serviços nas regiões Sul e Sudeste do Brasil, bem como de agricultores que apresentaram um maior grau de escolaridade e renda, possuindo maior número de computadores, quando comparados produtores rurais de outras regiões do país, renda e instrução formal. Os autores observam que essa concentração de serviços de internet, renda e aparelhos, apresenta um cenário preocupante quanto ao aumento da oferta de informações e conhecimentos, que podem auxiliar de forma positiva e significativa a produção agropecuária dos produtores rurais de pequeno porte.

Os autores ainda relatam:

\begin{abstract}
"que a concentração do acesso aos recursos de TICs entre os produtores com maior nível de escolaridade, principalmente no que se relaciona ao acesso à internet, reflete uma tendência apontada em alguns estudos de que, quanto maior o nível de instrução do produtor, maior sua capacidade de apropriar conhecimentos e tecnologias, o que pode contribuir para a exclusão digital das pessoas com baixo nível de instrução. Diante deste quadro, é imprescindível ampliar o acesso do produtor rural ao computador e à internet como uma das condições para que ele possa usufruir dos benefícios do uso da tecnologia da informação aplicada ao campo, sob pena da ampliação das assimetrias entre as denominadas, agricultura moderna e atrasada. (p.51)
\end{abstract}

Os autores observam a importância de políticas públicas que fomentem a democratização dessa tecnologia nos territórios rurais brasileiros, que caso não seja ofertada em amplitude, poderá comprometer as atividades econômicas de várias cadeias produtivas.

Bambini e Romani (2014), corroboram com os resultados encontrados por Mendes, Buainain e Fasiaben (2014), entrando em maiores detalhes os agravamentos que podem ocorrer nessa concentração de serviços e equipamentos, apensar de 
reconhecerem, nos dois trabalhamos as várias potencialidades dos TDICs. Os autores também relatam que:

apesar do potencial de contribuição que as inovações em TIC podem ter para aumentar a eficiência de processos, bem como a quantidade, a qualidade e a inserção dos produtos agropecuários no mercado, alguns aspectos vêm limitando sua adoção no setor, como: limitações de crédito e investimento, falta de infraestrutura de telecomunicações em áreas com baixa densidade demográfica, bem como de informação ou habilidades e competências para uso, e baixo nível de escolaridade de pequenos agricultores e da agricultura familiar. (p. 306).

Os autores ainda observam que a inserção das tecnologias que permitem a comunicação entre via internet tem sido mais lenta nos territórios rurais, quando se compara com outros agentes, mesmo esses pertencentes a mesma cadeia produtiva. E concluem que este serviço deve ser desenvolvido de forma ampla nos territórios rurais.

Em seus estudos Barbedo e Meira (2014) relatam que alguns serviços presenciais nas propriedades rurais, como o controle de pragas na produção agrícola por um técnico, podem ter um valor proibitivo para os pequenos agricultores. Os autores evidenciam que esse serviço sendo realizado remotamente pode diminuir seus custos, e ofertá-lo a um maior número de produtores rurais.

Indo por esse mesmo caminho Cruz (2014) descreve que:

\begin{abstract}
O uso das TIC tem permitido o encontro entre agricultores, especialistas e outros agentes para selecionar as melhores soluções tecnológicas para uma determinada situação ou localização. Serviços especializados dos setores públicos e privados, tais como o uso de satélites e sensores remotos, o armazenamento e o processamento de grandes quantidades de dados e as aplicações móveis têm sido utilizados para planejar a produção agrícola, evitar perdas de colheitas, minimizar riscos e melhorar a gestão da cadeia financeira. (p.354)
\end{abstract}

Como observado até esse momento há vários desafios para a democratização dos TDICs nos territórios rurais brasileiros, ainda mais quando falamos da sua inserção na agricultura familiar.

Entretanto, a sua introdução nas rotinas produtivas deste tipo de produção agrícola, não se trata apenas de fomento de políticas públicas, para ofertar computadores e redes de internet, mas sim um programa intenso e amplo de ensino- 
aprendizado para os produtores da agricultura familiar. As ações de ensinar e apreender sobre essas novas tecnologias passa por uma produção de novos sentidos e significados tanto nos agricultores e extensionistas rurais bem como nos desenvolvedores de softwares. Conceitos (significados) das novas palavras terão que ser aprendidos, outras irão surgir. Os caminhos internacionais é que irão determinar o sucesso ou fracasso no desenvolvimento das TDICs, a aproximação de novos sentidos, no mesmo horizonte situacional, no caso a propriedade rural pertencente a um determinado produtor rural (ZUIN, L.F.S.; ZUIN, P.B.; COSTA, 2019).

Todos esses novos sentidos e significados de forma pragmática darão suporte aos processos de tomada de decisão dos produtores rurais. Ferraz e Pinho (2017) relatam em seus estudos que:

\footnotetext{
As informações obtidas na prática agropecuária servirão para a tomada de decisão não apenas da propriedade que a gerou, mas também para propriedades que desenvolvam cultura similar e/ou estão localizadas na mesma área geográfica, além de técnicos e pesquisadores que possam vir a ter acesso a esse conteúdo. (p.41)
}

Portanto, essa amplitude e desdobramento de soluções entre propriedades e sistemas produtivos, mesmo que sejam semelhantes, devem passar necessariamente por adequações quanto ao local e tempo para serem implementadas. O emprego de TDICs deve necessariamente passar pelo olhar do produtor rural na rotina produtiva no campo. Posturas dialógicas devem ser tomadas para que o desenvolvimento de novas TDICs seja efetivo. O presencial não pode ser subsistido pelo remoto, e a idealização de um outro sujeito que não está presente. 


\section{MÉTODO DE PESQUISA}

Para esse estudo foi empregado o método de coleta de dados e informações a campo de abordagem qualitativa denominada estudo de caso, como preconizado nos estudos de YIN (2001). O método qualitativo se difere do quantitativo pois não utiliza instrumental da estatística para a análise dos dados e informações coletadas a campo; não é do seu interesse analítico mensurar unidades ou categorias semelhantes. Para o pesquisador, a análise qualitativa se presta ao seu entendimento sobre a natureza do fenômeno social estudado. Entretanto, tanto a abordagem qualitativa como quantitativa devem obedecer ao mesmo rigor científico, ou seja, devem possuir uma confiabilidade e validade. A confiabilidade diz respeito ao emprego de instrumentos de pesquisas de captura e mensuração constante de uma realidade presente no mundo concreto, permitindo que outros pesquisadores possam empregar em suas investigações os mesmos caminhos metodológicos e observar as mesmas interações entre os conceitos e informações. Quanto a validade da pesquisa qualitativa observa a capacidade do instrumento empregado na investigação em desenvolver e elaborar mensurações adequadas e precisas para que o pesquisador possa obter conclusões possíveis e corretas, podendo aplicar o que foi desenvolvido e descoberto em outros grupos de sujeitos, que sejam semelhantes, os quais não participaram da pesquisa original (RICHARDSON, 2008).

A produção do conhecimento humano apresenta relação com a capacidade de utilização de instrumentos cognitivos, que se evidência pela aplicação de competências de natureza semiótica e das inúmeras relações com o ambiente. Tal competência, em sua essência, possibilita ao ser humano estabelecer conceitos e definições, avaliar a composição de teorias e padrões, desenvolver novos espaços de debate, acessar e constituir recursos mecânicos ou informacionais, como uma matriz de possibilidades, para os mais diversos campos do conhecimento (PEROVANO, 2016).

O conhecimento científico no transcorrer do tempo tem passado por alterações, visto que não se configura como algo exclusivo de uma determinada 
sociedade ou época, nem tão pouco, pode ser considerado conclusivo ou definitivo. A ciência demanda do pesquisador elevado grau de dedicação, conhecimento a respeito do objeto de investigação e criteriosa análise e discussão dos resultados. A elaboração do conhecimento científico não pode ocorrer de modo artesanal e com inconsistentes e raros critérios metodológicos bem como seus resultados devem ser destinados a todos interessados; frente a esse conceito, a ciência deve ser produzida com atenção, cuidado, respeito e ética (PEROVANO, 2016).

Gerar informações científicas e proceder a sua divulgação são ações que integram um sistema complexo, em que o funcionamento é fundamental ao processo de produção científica. Pode-se, no entanto, considerar que dentre os principais meios de propagação do conhecimento científico figuram

os livros técnicos, os periódicos científicos e as dissertações/teses pela disponibilidade de acesso às pessoas (SOUZA et al., 2013).

É um ambiente que possui diversas formas para divulgar a produção científica assim como se intensificam as oportunidades de proceder às investigações, levantar informações e realizar interpretações e análises que vão constituir em conhecimento para utilização pela sociedade e pelo meio acadêmico. A produção científica representa um processo evolutivo em que sempre surgem conceitos novos ou maneiras inéditas de desempenhar atividades consolidando um saber até então desconhecido. Nas mais diversas áreas evidencia-se a importância do conhecimento. E, não é diferente com a Contabilidade, apesar dos estudos científicos realizados nesse campo constituírem uma área relativamente jovem quando comparadas com outras ciências. No entanto, é possível perceber que cada vez mais tem aumentado o número de trabalhos publicados na dimensão Contábil (PONTES et al., 2017).

Para Silva e Menezes (2003) e Mattar (1996) em seus estudos observam que uma pesquisa científica pode ser classificada de acordo com um grupo de elementos constitutivos e interativos. Ao cotejar os estudos dos autores com as variáveis constitutivas dessa dissertação pode-se ter:

a) natureza das variáreis: este estudo apresentou um conjunto de indagações de natureza qualitativa;

b) natureza do relacionamento entre as variáveis coletadas: essa 
investigação deseja a busca por conteúdos que a constituem como uma Pesquisa Descritiva, onde se buscará responder questionamentos que se iniciam com "quem, o que, quanto, quando e onde" e também oferta alguns questionamentos que podem defini-la como uma Pesquisa Causal onde as indagações possuem origem com "como e por quê";

c) quanto ao objetivo da pesquisa e grau de maturidade da pesquisa: por esse estudo pode ser exploratório, pois se trata de um assunto pouco explorado pela literatura especializada, ainda mais no contexto da pequena e média produção agropecuária;

d) quanto a forma da coleta de dados e informações: neste estudo foram aplicados dois roteiros de pesquisa sobre o tema da pesquisa um voltado para o técnico extensionista rural pertencente a CDRS-SAA-SP, contadores especialistas e produtores rurais;

e) quanto ao escopo da pesquisa quanto ao número de sujeitos entrevistados: para esse estudo foram entrevistados dois extensionistas rurais, dois contadores e dois produtores rurais;

f) quanto à possibilidade de controle das variáveis pesquisadas: buscouse entrevistar sujeitos que apresentam experiência nos temas desta pesquisa, como ativo biológico e internalização de novas tecnologias nos territórios rurais. Para um maior controle da amostra os técnicos extensionistas fazem parte da mesma organização que é a CDRS-SAA$\mathrm{SP}$ e contadores da regional de Limeira e também produtores rurais da mesma região; $\mathrm{e}$

g) quanto ao ambiente da pesquisa: entrevistas foram realizadas junto aos seis sujeitos entrevistados via e-mail.

Para a realização deste estudo foram entrevistados dois contadores, dois extensionistas e dois produtores rurais. Todos os sujeitos entrevistados atuam nas cidades que compõem o Escritório de Desenvolvimento Regional de Limeira, pertencentes a Coordenadoria de Desenvolvimento Rural Sustentável (CDRS-SAA$\mathrm{SP})$, sendo composta pelos seguintes municípios: Santa Gertrudes, Iracemápolis, Analândia, Cordeirópolis, Porto Ferreira, Ipeúva, Santa Cruz da Conceição, Corumbataí, Leme, Araras, Rio Claro, Pirassununga e Limeira.

Este estudo possui o objetivo de diagnosticar e propor encaminhamentos 
metodológicos didáticos visando a internalização da prática contábil denominada Ativo Biológico nas rotinas produtivas de propriedades rurais de pequeno e médio porte, localizadas nas cidades que compõem a Escritório de Desenvolvimento Regional da cidade de Limeira (EDR-SP) e da Coordenadoria de Desenvolvimento Rural Sustentável (CDRS-SAA-SP). Para a concretização deste objetivo serão percorridos dois caminhos metodológicos, o primeiro por meio da realização de um conjunto de entrevistas com especialistas contábeis, extensionistas e produtores rurais, onde se irá coletar conjuntos de relatos e informações sobre como realizar a prática contábil na propriedade rural. A realização e análises destes conjuntos de entrevistas será empregado o método de coleta de dados e informações o estudo de caso por meio da oferta de um roteiro de pesquisa com questões fechadas e semiabertas, para um conjunto de entrevistados. O segundo caminho se dará por meio dos conteúdos científicos coletados na literatura especializada, relativos aos temas da pesquisa como os caminhos didáticos para o uso de novas tecnologias nos territórios rurais, práticas contábeis e ativo biológico. A análise dos conteúdos coletados nas entrevistas a luz do referencial teórico terá como um dos resultados o desenvolvimento de encaminhamentos metodológicos didáticos, que visam a adoção da tecnologia contábil do Ativo Biológico nas rotinas produtivas de pequenos e médios produtores rurais. Com essas práticas contábeis espera-se que o produtor rural aumente a sua renda, contribuindo com a sua sobrevivência.

No presente trabalho também foram realizadas 6 entrevistas, isto é, 2 contadores, 2 extensionistas e 2 produtores rurais. A elaboração do questionário foi criada pelo próprio autor. Com os resultados seria possível entender melhor como a contabilidade rural é vista, quais são as dificuldades para a inserção da mesma perante os agricultores e até mesmo para os contadores.

Como se pode observar na Tabela 01, a produção média anual dos principais ativos biológicos presentes na EDR da região de Limeira (SP) em pequenas e médias propriedades rurais (CASA DA AGRICULTURA DE LIMEIRA/SP, 2019). 
Tabela 1 - Produção animal média anual dos principais ativos biológicos presentes na EDR da região da cidade de Limeira (SP).

\section{LEVANTAMENTO DE REBANHO}

\begin{tabular}{|c|c|c|c|c|c|c|}
\hline \multirow{2}{*}{ MUNICIPIO } & BOVINO LEITE & BOVINO CORTE & BOVINO MISTO & SUÍNOS & AVES POSTURA & \multirow{2}{*}{\begin{tabular}{|c|} 
AVES CORTE \\
(cobesos/ano) \\
\end{tabular}} \\
\hline & & $4+2+2+2+2$ & (cabeģas) & 4 & & \\
\hline ANALÂNDIA & 334 & 4.446 & 3.053 & 3.090 & 25.680 & 300.132 \\
\hline ARARAS & 4.082 & 435 & 1.537 & 1.722 & 445 & 624.020 \\
\hline CORDEIRÓPOLIS & 0 & 220 & 168 & 1.600 & 41.000 & 1.185 .000 \\
\hline CORUMBATAI & 404 & 14.019 & 3.139 & 178 & 230.065 & 5.085 .555 \\
\hline IPEÚNA & 921 & 7.930 & 1.356 & 910 & 57.261 & 607.700 \\
\hline IRACEMÁPOLIS & 0 & 60 & 98 & 28 & 250 & 0 \\
\hline ITIRAPINA & 1.111 & 9.341 & 8.128 & 160 & 460.084 & 1.597 .000 \\
\hline LEME & 1.059 & 614 & 820 & 22.263 & 5.000 & 315.750 \\
\hline LIMEIRA & 607 & 2.444 & 5.212 & 4.367 & 73.043 & 1.168 .270 \\
\hline PIRASSUNUNGA & 859 & 4.002 & 4.439 & 1.035 & 29.500 & 354.500 \\
\hline \begin{tabular}{|l|} 
PORTO FERREIRA \\
\end{tabular} & 546 & 1.311 & 776 & 201 & 1.060 & 250.000 \\
\hline RIO CLARO & 1.941 & 4.629 & 8.354 & 1.446 & 281.601 & 1.111 .850 \\
\hline SANTA CRUZ DA CONCEICCÃO & 504 & 4.105 & 1.827 & 1.048 & 180.200 & 1.703 .000 \\
\hline SANTA GERTRUDES & 23 & 204 & 181 & 18 & 0 & 0 \\
\hline TOTAL & 12.391 & 53.760 & 39.088 & 38.066 & 1.385 .189 & 14.302 .777 \\
\hline
\end{tabular}

Fonte: Casa da Agricultura de Limeira/SP (2019).

$\mathrm{Na}$ Tabela 2 encontram-se os principais volumes de explorações de animais de produção.

Tabela 2 - Principais explorações animais na EDR de Limeira (SP) 2016/17.

\begin{tabular}{|c|c|c|c|c|c|c|}
\hline \multicolumn{7}{|c|}{ EXPLORAÇÕES ANIMAIS } \\
\hline TABELA - Principais E & ões Animais, Esc & ório de Desen & vimento Regi & de Limeira, $\mathrm{E}$ & tado de São & ulo, 2016/17. \\
\hline \multirow{2}{*}{ MUNICÍPIO } & BOVINO LEITE & $\begin{array}{c}\text { BOVINO } \\
\text { CORTE }\end{array}$ & $\begin{array}{l}\text { BOVINO } \\
\text { MISTO }\end{array}$ & $\begin{array}{l}\text { SUÍNOS } \\
\text { (porcos) }\end{array}$ & $\begin{array}{c}\text { AVES } \\
\text { POSTURA }\end{array}$ & \multirow{2}{*}{$\begin{array}{l}\text { AVES CORTE } \\
\text { (cabeças/ano) }\end{array}$} \\
\hline & \multicolumn{5}{|c|}{ (cabeças) } & \\
\hline ANALÂNDIA & 334 & 4.446 & 3.053 & 3.090 & 25.680 & 300.132 \\
\hline ARARAS & 4.082 & 435 & 1.537 & 1.722 & 445 & 624.000 \\
\hline CORDEIRÓPOLIS & 0 & 220 & 168 & 1.600 & 41.000 & 1.185 .000 \\
\hline CORUMBATAÍ & 404 & 14.042 & 3.139 & 178 & 230.065 & 5.085 .555 \\
\hline IPEÚNA & 921 & 7.930 & 1.356 & 910 & 57.261 & 607.700 \\
\hline IRACEMÁPOLIS & 0 & 0 & 98 & 28 & 250 & 0 \\
\hline ITIRAPINA & 1.171 & 8.816 & 8.528 & 160 & 460.084 & 1.597 .000 \\
\hline LEME & 995 & 614 & 820 & 22.263 & 5.000 & 315.750 \\
\hline LEME & 995 & 614 & 820 & 22.263 & 5.000 & 315.750 \\
\hline LIMEIRA & 607 & 2.706 & 5.212 & 4.387 & 73.043 & 1.168 .270 \\
\hline PIRASSUNUNGA & 794 & 4.038 & 4.429 & 1.035 & 29.500 & 386.100 \\
\hline PORTO FERREIRA & 598 & 1.307 & 766 & 201 & 10.060 & 0 \\
\hline RIO CLARO & 1.941 & 4.629 & 8.354 & 1.446 & 281.601 & 1.111 .850 \\
\hline $\begin{array}{l}\text { SANTA CRUZ DA } \\
\text { CONCEIÇÃO }\end{array}$ & 504 & 4.105 & 1.827 & 1.048 & 180.200 & 1.703 .000 \\
\hline SANTA GERTRUDES & 23 & 204 & 181 & 18 & 0 & 0 \\
\hline TOTAL & 12.374 & 53.492 & 39.468 & 38.086 & 1.394.189 & 14.084 .357 \\
\hline
\end{tabular}

Fonte: Secretaria de Agricultura e Abastecimento, CDRS/IEA, Projeto LUPA. 
Com esse conjunto de entrevistas buscou-se responder ao objetivo desta pesquisa. De forma ampla o roteiro de pesquisa contará com os seguintes conjuntos de questionamentos:

a) Identificar uma série de abordagens específicas e produtivas que possam determinar as pequenas e médias organizações rurais pertencentes à área de EDR de Limeira (SP)

b) Identificar os elementos de gestão em torno do comportamento produtivodos pequenos e médios produtores rurais;

c) Coletar várias atitudes em torno dos novos processos de tecnologia degestão da organização de pesquisa;

d) Descrever a trajetória de emprego do processo de produção da propriedaderural nas convenções contábeis;

e) Estudar o potencial e as dificuldades nos processos de gestão e produçãoda organização relacionados à prática contábil de ativos biológicos.

A definição de categorização dos produtores rurais em pequeno e médio porte será empregada a desenvolvida pelo Banco Central do Brasil (2019), onde observa que:

a) pequeno produtor: até 4 módulos fiscais e até 415 mil reais de renda bruta anual;

b) médio produtor: entre 4 e 10 módulos fiscais e entre 415 mil e 1 milhão dereais de renda bruta anual; e

c) grande produtor: mais que 10 módulos fiscais e mais de 1 milhão de reaisde renda bruta anual.

De forma pontual essa investigação busca responder o seguinte questionamento: quais os caminhos didáticos para a internalização de novos conhecimentos, devem ser percorridos pelos extensionista rurais e contadores, visando o emprego da prática contábil do Ativo Biológico em pequenas e médias propriedades rurais paulistas. Este estudo foi aprovado pelo Comitê de Ética em Pesquisa com Seres Humanos (CEPH) da Faculdade de Zootecnia e Engenharia de Alimentos da Universidade de São Paulo, com o número CAAE 27810319.9.0000.5422. 


\section{RESULTADOS E DISCUSSÃO}

Os resultados aqui apresentados são oriundos das entrevistas semiestruturadas e da análise e percepção das entrevistas realizadas com contadores, extensionistas e produtores rurais. Buscando apresentar os resultados obtidos no presente estudo, este capítulo esta estruturado em duas subseções. A primeira apresenta a características dos contadores, extensionistas e dos produtores rurais. A segunda, a percepção dos entrevistados em relação ao Ativo Biológico.

As entrevistas realizadas, junto aos contadores, extensionistas e produtores rurais, foram levadas a efeito, inicialmente via telefone fixo, celular e também utilizado email, tendo em vista, as observações sanitárias a serem seguidas durante a pandemia de COVID-19, que durante a realização das mesmas, tiveram de ser criteriosamente seguidas, de distanciamento social e seguir as normas impostas pelos Governos Federal, Estadual e Municipal.

Nesse sentido, busca-se apresentar e analisar as práticas de gestão adotados pelos entrevistados, buscando atender o objetivo desse estudo

\subsection{Características dos Contadores, Extensionistas e Produtores Rurais}

Esta subseção visa analisar o perfil dos supracitados, analisando a faixa etária da maioria dos entrevistados, concentra-se entre 37 a 70 anos de idade.

O contador 1 é um profissional com formação acadêmica (Contador e Economista), com experiência de mais de 30 anos no segmento, com uma carteira composta também de Produtores Rurais da região da cidade de Limeira (SP), de pequeno e médios portes. $O$ Contador 2 , também um profissional com boa formação acadêmica, com cursos de pós-graduação no segmento contábil. Os dois extensionistas rurais entrevistados possuem a formação em Engenharia Agronômica e ambos trabalham na EDR de Limeira (SP).

O produtor rural 1 possui formação secundária incompleta. É dono de uma propriedade de 6 alqueires, com a produção de hortaliças e frutas, combinado com a criação de aves (fornece para uma organização de médio porte). O mesmo pertence a uma associação de produtores locais e também faz parte de uma cooperativa de produtores. O produtor rural 2 possui formação de ensino fundamental. É dono de 
uma propriedade de 8 hectares, da qual esta produz leite e corte.

\subsection{Potencialidades e dificuldades para introdução do ativo biológico em propriedades rurais de pequeno porte}

O Contador 01 durante a entrevista observou a dificuldade de mudança dos produtores rurais de pequeno porte do sistema de livro caixa para a contabilidade formal, com o seu entendimento do registro do quotidiano de suas atividades, a leitura e adoção de novos procedimentos do Instituto Internacional e mesmo do CRC/SP. Para este entrevistado um dos motivos pelos quais não ocorre a internalização dessa tecnologia contábil nas rotinas produtivas na propriedade rural deste porte acontece pela absoluta falta de tempo para educar o produtor rural nos detalhes dessa tecnologia. Ele observou que também não teria tempo para implementar este conhecimento no cotidiano de seus clientes. Já que grande parte do seu público não possui formação e qualificação escolar para preencher as planilhas, informando corretamente os dados oriundos dos seus sistemas produtivos. Em nenhum momento do encontro o sujeito entrevistado relatou a sua falta de conhecimento pedagógico o qual é necessário para a introdução da tecnologia no público que atende. As dificuldades eram falta de formação do produtor rural e sua disponibilidade de pouco tempo para o momento do ensino. Fatores que certamente influenciam neste processo pedagógico nos territórios rurais, independente da tecnologia que esteja sendo implementada. Entretanto, os técnicos contabilistas que prestam estes serviços nos territórios rurais devem assumir o seu papel como educador, visando o desenvolvimento social, econômico e ambiental sustentáveis.

O Contador 02 durante a entrevista relatou que possui em sua carteira de clientes produtores rurais de pequenos e médios porte. Durante a entrevista observou que não tinha conhecimento do emprego da tecnologia dos Ativos Biológicos nas rotinas contábeis de seus clientes. Como relatado no Contador 01 ele observa a dificuldade de formação e conhecimento dos produtores rurais de migrarem dosistema de livro caixa para o da contabilidade formal. Apesar de todas as benesses que poderiam advir deste sistema contábil.

O Extensionista rural 01 observou no seu relato que não tinha conhecimento do emprego da prática contábil do Ativo Biológico nas rotinas dos produtores rurais 
que assessora. Por sua experiência de 27 anos em campo, apesar de todas as ferramentas que as organizações públicas de extensão rural oferecem para o pequeno e médio produtor rural, por causa do nível de escolaridade e crer em seu conhecimento prático, o produtor rural não conseguiria visualizar como poderia melhorar as suas performances produtivas em suas rotinas, com a introdução da tecnológica contábil do ativo biológico, em sua contabilidade formal. Outro entrave técnico é que esse público adquire empréstimos nas Instituições Financeiras em nome da pessoa física, com garantia de seu patrimônio pessoal.

A Extensionista rural 02 relatou que o produtor em geral tem dificuldade de confiar no conhecimento científico e gerencial, como por exemplo novas tecnologias contábeis como o ativo biológico. Este profissional acredita essa situação se deve por possuem baixa escolaridade. Ele descreveu que em suas rotinas de trabalho é frequente encontrar produtores rurais com dificuldades de preencher planilhas e documentos e utilizar as ferramentas propostas. E não faz parte de parte significativa da rotina de trabalho dos produtores rurais deles a gestão financeira e na importância das práticas contábeis nos seus processos produtivos. Geralmente, eles delegam a gestão para um escritório de contabilidade e os contadores não tem por hábito assessorar ou indicar caminhos nesta direção de introduzir novas tecnologias contábeis no campo. Na prática não possuem consciência de suas benesses futuras da internalização desses novos caminhos contábeis.

O produtor rural 1 faz o uso da contabilidade em regime de caixa. Segundo Crepaldi (2012), os obstáculos encontrados pelos produtores rurais é manter os registros de controle e separar os gastos pessoas, bem como a falta de notas fiscais, extratos bancários e outros documentos pertinentes que possam facilitar assim essa prática. Já para Vilckas (2004), os cultivadores são obrigados a ter uma visão extensa do processo de produção. Para tanto, os supracitados necessitam entender e observar os elementos internos como sistema, como: processo, entrada, saída e avaliação de financiamento. Neste caso, o produtor rural e o contador do supracitado não possui conhecimento sobre o ativo biológico.

O produtor rural 2 entrevistado não possui domínio das Tecnologias da Informação, e também em muitos aspetos de controle da gestão da propriedade, como no caso dos elementos contábeis dos seus processos produtivos. Um dos aspetos importantes levantados e que dizem respeito a determinação do valor dos ativos 
biológicos foi que este sujeito utiliza seus conhecimentos práticos para formalizar preços nos seus produtos. Entretanto, este produtor rural deseja ter mais conhecimento de operar planilhas de custo, conhecimentos de gestão para melhor gerir sua propriedade. Como relatado pelo extensionistas e contadores entrevistados, a dificuldade de registar e obter dados da sua produção dificulta a implementação e mudança do livro caixa para a contabilidade formal, a qual exige formalização de dados. Sendo essa transformação fundamental para introduzir a nova tecnologia do ativo biológico nas suas rotinas produtivas.

Portanto, no tocante aos entrevistados, conforme se depreende de suas respostas, podemos afirmar que os autores, como os entrevistados relatam as dificuldades, de internalização de controles contábeis e mudança do atual livro caixa, para a contabilidade formal.

\subsection{A percepção dos entrevistados em relação ao Ativos Biológico}

Os entrevistados foram inqueridos a respeito do Ativo Biológico. De acordo com os Contadores 1 e 2 existe uma grande dificuldade em mensurar o valor justo de mercado para ativos biológicos de pequeno e médio produtores rurais. Entretanto, para Rodrigues et al. (2016, p. 179)

\footnotetext{
O ativo biológico pode ser mensurado ao valor justo menos as despesas de vendas no momento do reconhecimento inicial e no final de cada período de competência exceto para casos em que o valor justo não pode ser mensurado de forma confiável
}

Muitas vezes o valor justo não é auferido. Sendo assim, os produtores rurais terão que usar outras formas de mensurar os valores de seus ativos e com isso tornar possível o reconhecimento do preço de mercado. Os Contadores entrevistados ainda acrescentam que seus clientes utilizam o regime de fluxo de caixa para declararem seus impostos como pessoa física tornando assim não necessário a utilização das demais peças contábeis. Para a elaboração da DFC (Demonstração do Fluxo de Caixa) deverão ser realizados de forma que o objetivo proposto seja alcançado, ou seja, atingir o sucesso previsto.

Para alcançar o êxito da demonstração financeira, várias técnicas serão utilizadas, permitindo assim a elaboração da DFC (Demonstração do Fluxo de Caixa) 
em várias organizações. A contabilidade não é frequentemente usada para o tipo de elaboração citada.(IUDícIBUS; MARTINS; GELBCKE, 2000, p.355).

Ambos os contadores utilizam ferramentas administrativas na atividade rural. O autor Godinho (2015) ressalta que com o uso de ferramentas administrativas e tomadas de atitudes adequadas, o sucesso será alcançado pela empresa. Porém, o autor expõe alguns fatores que possam limitar o desenvolvimento da gestão rural no Brasil. Os obstáculos incluem:

a) Os produtores e profissionais da assistência técnica e extensão rural têm dificuldade de compreender o arcabouço teórico e metodológico do processo de gestão rural do país.

b) Existe um certo grau de desconfiança entre os fabricantes e até mesmo o pessoal técnico quanto à necessidade e eficácia do uso de processos de gestão maisprecisos, por exemplo, planos formais envolvendo ações de longo prazo ou controle personalizado das atividades de fluxo de caixa existentes. Essa atitude negativa podeestar relacionada a diversos fatores incontroláveis que afetam os resultados econômicos das empresas rurais e dificultam o processo de gestão.

c) O custo do serviço de uma assistência agrícola mais abrangente (incluindo tecnologia de gestão) é mais alto, o mercado carece de profissionais relativamente independentes, não tem relacionamento com empresas que mantêm relações comerciais com produtores rurais e está disposto a assumir certas funções administrativas de empresas rurais.

d) O custo de implantação de um sistema de registro contábil é elevado, principalmente pela necessidade de coleta de dados precisos nas condições in loco, e pela dificuldade de geração e interpretação de informações relacionadas ao processo decisório das empresas rurais.

Para os Contadores entrevistados, os produtores de médio e pequeno não possuem uma estrutura suficiente para implantar esse nível de controle e a presença desse tipo de controle e informação é mais comum em médias e grandes empresas do agro. Para Crepaldi (2012), a dificuldade do produtor rural é de realizar os registros de controle e em separar os gastos pessoas bem como inexistência de notas fiscais, extratos de conta e outros documentos que poderia facilitar essa prática. 
Na contabilidade, a DFC (Demonstração do Fluxo de Caixa) é a peça mais importante e de maior interesse paraos bancos pois, é através deste que o banco e/ou outros interessados conseguem saber se o negócio é viável financeiramente e se este possui capacidade de pagar a parcela de um futuro empréstimo/financiamento. Para Oliveira (2020), a peça chave das demonstrações contábeis é o DFC (Demonstração do Fluxo de Caixa). Através dele que as operações bancárias desejadas poderão ou não serem realizadas, isto é, o ativo e o passivo são plenamente demonstrados. No entanto, as demonstrações contábeis são divididas em: Balanços, sendo estes os direitos e as obrigações da corporação, os Demonstrativos Anuais, Demonstrativos de Fluxo de Caixa, Demonstração do Valor Agregado, Notas Explicativas e até mesmo as representações de tabelas de análises que ajudam a contribuir com a organização (OLIVEIRA, 2020).

Portanto, se a empresa está inadimplente ou não, dificilmente está será demonstrada no DRE e nem sempre o lucro ou prejuízo terá um sinal de quebra, porém, o DFC sinaliza a falência em curto prazo. Com isso, o produtor dificilmente migrará do regime de caixa, pois este traduz a sua realidade.

Para os Extensionistas 1 e 2 os produtores rurais possuem dificuldades na organização dos dados contábeis relativos as suas rotinas produtivas, ou seja, nos custos e nas receitas. Além da falta de orientação técnica não oferecida devidamente pelos órgãos competentes do Estado, levando assim os produtores rurais em geral a não realizarem com sucesso seus empreendimentos. Devido a falta de tecnologia e por questões financeiras ou até mesmo falta conhecimento, os produtores rurais, principalmente os pequenos não utilizam ferramentas adequadas. (NANTES; SCARPELLI, 2001).

O pequeno e médio produtor rural exerce atividade, a qual seja mais lucrativa, em outras palavras, visam mais a informalidade do que a formalização. Para os extensionistas a baixa escolaridade dos produtores bem como a falta de cultura cooperativa promovem a dificuldade. Para Silva, Rech e Rech (2010), afim de a agricultura familiar ou pequena empresa para obterem resultado positivo, deverão recorrer à ajuda aos sindicatos, cooperativas e outras entidades que trabalham com o produtor rural.

Do ponto de vista da Extensão Rural Pública, o responsável por motivar o produtor a se apropriar das políticas públicas disponíveis bem como pela orientação 
para que se desenvolva de forma sustentável, ainda falta uma definição melhor de diretrizes de atuação, uma melhor articulação de trabalho entre os diversos agentes de desenvolvimento, incluindo ai os pesquisadores bem como uma melhor definição de indicadores de desenvolvimento, sem considerar a valorização do trabalho do extensionista que vem sendo relegada a segundo plano ao longo do último ano. De acordo com o Diário Interativo (2012) o extensionista rural é o profissional que faz a ligação entre o produtor rural e os governos atuais, além de ajudar na elaboração de projetos e estratégias de produção, e auxilia no desenvolvimento geral das propriedades. Ainda há muito a conquistar em diversas frentes de atuação para que os produtores cheguem a formalizar seus processos em documentos e planilhas.

Os extensionistas relatam ainda que os gestores da atividade agropecuária sentem as mesmas dificuldades que os pequenos empresários de outros setores. $O$ conhecimento do pecuarista enfrenta várias barreiras em sua atividade: dificuldade em reconhecer a importância na utilização das ferramentas "planilhas e documentos" ; não tem o hábito de registrar ocorrências financeiras ou de campo "a famosa caderneta de campo"; desanimo frente à quantidade de exigências documentais sem a devida orientação, o que resulta no que chamamos de "terrorismo"; baixa remuneração de seu trabalho além de admitir a própria dificuldade frente às exigências dos atuais ambientes de trabalho. Para Vilckas (2004), o agricultor necessita de uma visão ampla do processo produtivo. Para isso o supracitado precisará entender e visualizar os elementos internos como um sistema como: processos, entradas, saídas e avaliação do seu financiamento).

Alguns produtores acreditam que administrar sua atividade pode trazer algum efeito positivo, porém, dadas a dificuldade de fazê-lo e a falta de hábito, na prática pensam que podem muito bem passar sem ela. $O$ produtor, ressalvadas algumas exceções, só faz algum tipo de gestão, como reunião de documentos, cadastros, Cadastro Ambiental Rural, Gestão de Defesa Animal e Vegetal, obtenção de licenças, se for forçado, ameaçado com algum tipo de multa, autuação, exclusão de programas e para obter benefícios junto às instituições financeiras ou governamentais. Segundo Crepaldi (2012), para ter um bom desempenho nas atividades agrícolas, não basta o agricultor ter atenção somente para os processos produtivos, mas também para ações gerenciais da propriedade. Não basta saber quanto, como e o que produzir, é necessário analisar o que foi planejado, medir os lucros e prejuízos e os resultados 
alcançados na colheita.

No caso de produtores em processo de Transição Agroecológica ou que estão buscando certificação orgânica, de boas práticas de produção agropecuária, 0 planejamento técnico faz parte do processo, sendo, portanto, a gestão financeira uma consequência benéfica. Na média, o produtor não acredita na importância das práticas contábeis.

Devido à falta de capacitação dos produtores mais antigos, os mais jovens passam a utilizar melhor o uso de ferramentas contábeis, as quais irão auxiliar na otimização de seu processo produtivo com mais êxodo. Embora tenham essa visualização, as atividades rurais desses jovens tornam-se enfraquecidas devido ao êxodo rural. Para Lourenzani (2006) o grau de escolaridade dos agricultores familiares influencia o modo com o qual eles trabalham com as suas atividades, sejam estas gerenciais ou de produção.

Algumas razões pelas quais possivelmente não são aplicadas as rotinas gerenciais como: a gestão contábil que é delegada ao escritório de contabilidade apenas para a elaboração do Imposto de Renda de Pessoa Física; o assédio de vendedores de insumos ansiosos por cumprir metas desvinculado do processo de assistência técnica compreendendo como planejamento, acompanhamento e avaliação não contribuindo este positivamente; na prática não existem rotinas gerenciais; a estrutura da Extensão Rural Pública, que poderia influenciar positivamente para mudar essa situação, não é robusta o suficiente para fazer frente às necessidades dos produtores entre outros.

Para o produtor rural, devido a sua baixa instrução e falta de conhecimento, o Ativo Biológico não interfere no progresso da sua propriedade rural. Conclui-se que eles não têm consciência do valor do supracitado tema.

Os encaminhamentos para alterar a realidade gerencial na produção agropecuária de pequeno e médio porte seriam:

a) Fortalecer a Extensão Rural Pública, articulada com a pesquisa;

b) Utilizar canais de comunicação diversos esclarecendo a importância das práticas gerenciais;

c) Fortalecer e privilegiar empreendimentos de base agroecológica; entre 
outros.

O Produtor rural 1 faz parte de cooperativas e associações. Já o produtor 2 não faz parte de associações e cooperativas, sendo, portanto, um produtor independente. Segundo Balem (2016), a associação é uma organização que visa a promoção da sociedade, educação, assistência cultural, representação política, defesa dos interesses de classe e caridade. As cooperativas têm fins essencialmente econômicos. Seu principal objetivo é viabilizar no mercado o negócio de produção de seus colaboradores. Em uma cooperativa, os associados são os donos do imóvel e os beneficiários dos benefícios que o processo de sua organização proporcionará. As cooperativas de trabalho, como as cooperativas de produção, beneficiam as próprias cooperativas.

O produtor 1 relata que possui dificuldades em formalizar, além da falta de tempo do dia a dia, existe também a falta de especialização em tecnologia. Já o Produtor 2 não participa de associações e nem de cooperativas e não possui nenhum conhecimento do ativo biológico.

Ele também não faz uso de planilhas para seu contador. Entretanto, ambos os produtores acreditam nas práticas contábeis e com isso desconhecem o Ativo Biológico. De acordo com o CPC 29, o Ativo Biológico é umanimal e/ou planta.

Portanto, a metodologia empregada para a divulgação dos ativos biológicos e produtos agrícolas seria através de organizações de palestras, sendo estas ministradas por contadores e extensionistas, na qual seria explicado sobre o assunto tanto aos contadores como também para os produtores rurais. Além também das entregas de panfletos e da campanha de marketing direto para mensurar o assunto.

Embora os agricultores sejam resistentes aos padrões estabelecidos é necessário que os supracitados sejam treinados e de alguma forma qualificados pelos extensionistas ou pelos contadores para que assim possam se transformar em agricultores mais criativos e sugestivos.

E com a inserção que os extensionistas fizeram em relação aos novos elementos, estes podem subsidiar o levantamento dosprocedimentos exercidos pelos agricultores. De acordo com Balem (2015) o ponto devista dos contadores e até mesmo dos extensionistas são pertencentes aos dos agricultores, no qual estes podem desenvolver técnicas se baseando em um contexto real. Entretanto os agricultores não sabem estabelecer suas próprias estratégias. 
No entanto, os conhecimentos dos agricultores ou o progresso de novas habilidades pode ser desenvolvida de várias maneiras como: reuniões, cursos, viagens de estudo, troca de conhecimento, entre outros.

Tanto os extensionistas quanto os contadores necessitam expandir seus conhecimentos para que assim os supracitados possam ajudá-los no processo de aprendizado coletivo, onde o conhecimento técnico e o conhecimento dos agricultores formulam outros entendimentos. Balem (2015) ressalta que mesmo que os agricultores sejam capazes da utilização dos meios de comunicação modernos, estas informações seriam como "bombardeios" nos quais os urbanistas sofrem diariamente. No entanto, isto não ocorre nas áreas rurais. Já a troca estipulada entre os extensionistas e agricultores não são capazes de utilizar expressões ou termos dos quais os agricultores não entenderiam. Sendo assim, é importante o diálogo vivenciado na situação do agricultor, isto é, com uma linguagem de fácil conhecimento e entendimento.

A autora ainda salienta que os agricultores são o principal corpo de prática envolvido no trabalho diário, por isso raramente se comunicam na forma de salas de aula ou palestras. Outra questão fundamental é que o cronograma de atividades para a ação de promoção deve ser planejado de forma que respeite as características dos produtores, e sua anuência precisa ser adquirida antecipadamente. Baseado na literatura (ZUIN et al, 2019; ZUIN; ZUIN, 2014), algumas sugestões de como os extensionistas ou contadores podem utilizar para ensinar melhor os agricultores:

a) Ao conduzir atividades de treinamento envolvendo materiais audiovisuais, certifique-se de que o idioma, o tamanho da fonte e a organização são úteis para o trabalho, e não o contrário. Um problema básico é informar-se sobre a formação escolar do grupo, pois os materiais audiovisuais dela dependem em vão. Seprecisar usar esses materiais, use mais fotos e desenhos representativos em vez de páginas longas. Existe queda de energia frequentes nas áreas rurais.

b) Marcar uma reunião para começar muito cedo ou terminar muito tarde pode surpreender os agricultores, pois a fazenda tem atividades para acontecer no início da manhã e à noite.

c) As reuniões do grupo devem ser realizadas durante os turnos que os agricultores consideram os melhores, mesmo à noite. Cada grupo se reúne sempre no dia mais adequado da semana. Em certas épocas do ano, é 
praticamente impossível reunir agricultores, como na época da colheita. Por outro lado, a duração dessas reuniões deve ser de no máximo 3 horas para evitar coisas cansativas e chatas. Abertura do evento de discurso e se um discurso for essencial, certifique-se de que seja curto.

d) As atividades devem ser agendadas com antecedência, pois a rotina dos agricultores é dinâmica, fazendo com que os mesmos esqueçam deste compromisso.Por outro lado, encontros de última hora tendem a ter baixa presença.

e) Fazer a utilização da linguagem quotidiana, pois os termos científicos e técnicos devem ser passados aos agricultores de uma maneira que estes possam entender. É importante optar pelo diálogo com os agricultores não só simplesmente falar com eles.

f) Nunca desconsidere os conhecimentos dos agricultores, pois, estes devem saber mais do que deixam transparecer. Por mais domínio técnico que possase ter sobre um determinado assunto, sempre haverá o conhecimento do outro lado. 


\section{CONSIDERAÇÕES FINAIS}

Ao analisar este estudo, o caminho da prática contábil para o produtor rural é um grande desafio, pois na maioria dos casos, o planejamento, os controles e os registros são realizados de forma específica em alguma atividade. A pesquisa revela que os contadores e os extensionistas possuem uma compreensão do Ativo Biológico, enquanto que os produtores rurais não possuem.

Os produtores rurais entrevistados afirmam que a falta de gestão contábil pode inviabilizar as atividades, portanto, conclui-se que os produtores rurais têm a percepção da importância da gestão, mas as ferramentas utilizadas pelossupracitados são muitas vezes informais.

Os produtores rurais de pequenas e médias propriedades possuem riscos e prejuízos reduzidos quando usam as ferramentas contábeis mais sofisticadas.

Este estudo demonstra que nem sempre os produtores rurais possuem o conhecimento e a capacitação necessária para desenvolver as práticas contábeis. Diante de tantos obstáculos, assistimos há longo tempo, jovens trocando o meio rural pelo meio urbano, prática conhecida como êxodo rural.

Observa-se a necessidade dos pequenos e médios produtores rurais a busca pela capacitação através de órgãos auxiliadores desta atividade.

Esse estudo demonstrou que as práticas contábeis mesmo não estando presente nas propriedades rurais, acompanhado de deficiência de técnicas e ferramentas contábeis, existem vários produtores rurais que ativam outras práticas satisfatórias como o acompanhamento dos resultados e observando as melhorias produtivas.

Esse estudo é essencial para buscar mecanismos e ferramentas que atendam as necessidades dos produtores rurais, e para melhoria no gerenciamento de suas propriedades.

Diante da importância da Contabilidade para a legalidade e sobrevivência da empresa rural, e também com relação às demais entidades do agronegócio, conhecer os conceitos e características que envolvem esta atividade, principalmente, quanto às normas que regulamentam essa atividade, para este caso - CPC 29, que orienta o tratamento contábil para os ativos biológicos e produtos agrícolas, torna-se um fator importante para aquisição de conhecimento. Neste 
cenário produtivo essa dissertação visa contribuir para:

a) produtor rural de pequeno e médio porte: com as informações obtidas e métodos a serem implementados nestes sistemas produtivos, e informando os mesmos dos benefícios juntos a Bancos, Companhias Seguradoras, Fornecedores e Clientes, certamente ao tomarem conhecimento através dos Institutos Estaduais do Agronegócio, e de seus contadores, em efetuar contabilidade formal para obter os benefícios oriundos desta modalidade de gerenciamento de sua propriedade. Ao determinar os seus números, auxiliando as decisões sobre o que plantar, em que época vender, adquirir ou não plantel para criar na propriedade, de pleno conhecimento dos números, certamente todas as decisões gerenciais estarão amparadas e lastreadas por dados fundamentais para a tomada correta de decisões. Conjunto de ações que possam contribuir com a sobrevivência dos pequenos e médios produtores rurais; e

b) profissionais que atuam no agronegócio: ofertar para essas pessoas metodologias didáticas e habilidades internacionais, que possam internalizar com sucesso em pequenas e médias propriedades rurais, os caminhos da prática contábil do Ativo Biológico nas suas rotinas produtivas.

Convém salientarmos com o devido ênfase, que o $\mathrm{CRC} / \mathrm{SP}$, tem se empenhado com os profissionais que fazem parte de seu acervo de palestrantes, realizando nas Delegacias Regionais, reuniões com os Contadores, demonstrando para os mesmos o alcance e o benefício do Ativo Biológico, nas pequenas e médias propriedades rurais, visando informar e incentivar os profissionais da contabilidade em inserir em seus respectivos cotidianos e também apresentarem aosseus clientes do agronegócio, as características que envolvem o mesmo e os benefícios fiscais, econômicos e financeiros que podem advir de sua implementação na propriedade rural.

E como trata-se de uma cultura de médio e longo período de tempo de absorção pelas partes envolvidas, os atores: contadores, extensionistas e produtores rurais, devem ser apresentados ao Ativo Biológico, de forma acadêmica, expondo toda sua miríade de benefícios a serem colhidos com sua implementação na gestão 
econômico/financeira e contábil da propriedade, ser inserida em suas atividades profissionais, controles financeiros de fácil utilização e apresentar de formadidática, simples e de fácil compreensão e ir acrescentando um passo a passo, de forma do usuário fazer dela uma ferramenta importante no sucesso de seu negócio rural.

E a Receita Federal, poderá paulatinamente alterar a forma de apresentação dos relatórios numéricos das pequenas e médias propriedades rurais, o sistema de livro caixa, será encerrado dentro de um período muito curto e todos devem ser transferidos através de comunicado legal pelo Governo Federal, a apresentar suas declarações, na forma da contabilidade formal. E a sinalização dos órgãos da Receita Federal nesta direção, certamente todos os envolvidos na atuaçãode assessoria, orientações técnicas e ensinamentos de procedimentos, tais como os:contadores e extensionistas, devem estar preparados para esta mudança de cenário, que será efetuada em um futuro muito próximo.

Uma mudança de cultura neste segmento, com a implementação de um conhecimento científico, demanda uma ferramenta bem construída pelo $\mathrm{CRC/SP}$, na expansão do conhecimento das normas editadas pelo Instituto Internacional de Contabilidade e o Órgão Federal da Contabilidade que publica as normas a serem seguidas pelos profissionais do setor, e vem incansavelmente promovendo lives, palestras, aos seus associados, com o intuito de instrui-los a absorver este conhecimento e repassa-lo e implementa-lo aos seus clientes do agronegócio.

As formações dos cursos de Contabilidade, em suas grades de matérias, muitas Universidades e Faculdades, não possuem especificamente a difusão do conhecimento do agronegócio, contabilidade rural, financiamento e seguros rurais, não fomentando o conhecimento e preparação dos alunos neste segmento tão importante de nossa economia nacional que representa um montante de $30 \%$ (trinta por cento) do PIB (produto interno bruto) e a grande força da exportação de seus produtospara todo o planeta. E como estão se fazendo notar na economia nacional, os cursosde Ciências Contábeis, devem rever suas grades de aulas e inserindo o ensino da contabilidade rural e os outros conhecimentos específicos do agronegócio.

As capacitações oferecidas para o contador, extensionista e produtor rural, apesar de baixa adesão no passado, começam a ganhar força na atualidade, tendo em vista as mutações havidas no agronegócio nacional e internacional e de patinho feio, está se transformando em um cisne a ser observado e admirado pelo mercado.

Existe um grande caminho a ser trilhado em colocar a ferramenta de gestão 
dos produtores rurais em formalizar seus processos em documentos e planilhas, ou seja, muito trabalho ainda a ser realizado em muitas frentes de atuação entre os triunviratos que fomenta esta linha: contadores, extensionistas e produtores rurais.

Inserir novos hábitos especificamente a gestão financeira para a apuração de resultados, tomadas de decisão e planejamento como uma prática diária do pequeno e médio produtor rural, mostrando que a prática da gestão contábil é benéfica para seu negócio. E ficar ciente que simplesmente delegar ao um escritório de contabilidade a gestão contábil é temerária, pois o contador muitas vezes apenas preenche formulários governamentais necessários e não oferece assessoria e consultoria de como melhorar seus números da propriedade, e não propõem aos seus clientes rurais, rotinas gerenciais de seus números para tomarem as melhores decisões. Falta consciência de ambas as partes envolvidas no processo.

Canais de comunicação devem ser construídos para a importância das práticas gerenciais, desenvolvimento de aplicativos gerenciais para smartfones, treinar exaustivamente os produtores e técnicos sistematicamente na utilização das práticas e apps. Devem fazer parte deste esforço coletivo as Instituições Governamentais de extensão rural e pesquisa, instituições financeiras, órgãos de classe e agentes do desenvolvimento e também um esforço da academia também com sua parcela de contribuição de desenvolvimento. 


\section{REFERÊNCIAS BIBLIOGRÁFICAS}

ALMEIDA, A.; ANJOS, M.A.D. A importância da contabilidade rural como ferramenta de Gestão para as pequenas propriedades rurais: uma revisão bibliográfica. $\quad$ p.1-20, $2018 . \quad$ Disponível em: <http://repositorio.fucamp.com.br/bitstream/FUCAMP/347/1/Importanciacontabilidade r ural.pdf.> Acessado em: 16 de set de 2019.

ALVES, M.T.V.D.; PASCOAL, M.O.A.S.F. Mensuração e reconhecimento contabilístico dos ativos biológicos: um estudo de caso. Revista Contemporânea de Contabilidade, Florianópolis, v. 14, n. 31, p. 46-66, jan./abr. 2017.Disponível em: $<$ https://periodicos.ufsc.br/index.php/contabilidade/article/download/21758069.2017v 14n31p46/34037>. Acessado em: 8 set. 2019.

AMARO, H.D.; SOUZA, A.; SILVA, E.D. Ativo biológico: conceituação, reconhecimento e mensuração. In: CONGRESSO BRASILEIRO DE CUSTOS, 23., 2016, Porto de Galinhas, PE. Anais CBC. São Leopoldo, RS: ABC/, 2016. Disponível em: <https://anaiscbc.emnuvens.com.br/anais/article/download/4107/4108>. Acessado em: 8 set. 2019.

ATKINSON, A. A. et al. Contabilidade Gerencial. 2. ed. São Paulo: Atlas, 2008.

BAKHTIN, M. Metodologia das ciências humanas. In:_. Estética da criação verbal. Trad.: Paulo Bezerra. 6. ed. São Paulo: Martins Fontes, 2011, p. 393-410.Disponível em: <http://www.planalto.gov.br/ccivil_03/LEIS/L8171.htm>. Acessado em:11 jan. de 2020.

BALEM, T.A. Associativismo e Cooperativismo. Colégio Politécnico.Santa Maria, 2016.

BAMBINI, M.D.; ROMANI, L.A.S.Mercado de AgroTIC e transferência de tecnologia. In: MASSRUHÁ, S.M.F.S. Tecnologia da informação e comunicação e suas relações com a agricultura. Brasília, DF: Embrapa, p. 306-330, 2014. 
BANCO CENTRAL DO BRASIL - BCB. Crédito: Programa Nacional de Fortalecimento da Agricultura Familiar. Disponível em: <https://www3.bcb.gov.br/mcr/manual/09021771806f4fb1.htm > Acessado em: 21 nov. de 2019.

BARBEDO, J.G.A.; MEIRA, C.A.A. TIC na segurança fitossanitária das cadeias produtivas. In: MASSRUHÁ, S.M.F.S. Tecnologia da informação e comunicação e suas relações com a agricultura. Brasília, DF: Embrapa, p. 159-189, 2014.

BARBOSA, A. C. Contabilidade Básica. 1. ed. Curitiba: Juruá, 2006

BARROS, C. D. C.; SOUZA, F. J. V. D; ARAÚJO, A. O.;SILVA, J. D. G. D; SILVA, M. C. D. O impacto do valor justona mensuração dos ativos biológicos nas empresas listadas na BM\&FBovespa. Revista de Contabilidade do Mestrado em Ciências Contábeis da UERJ (online), Rio de Janeiro, v. 17, n. 3, p. 41 -p.59, set /dez, 2012. Disponível em: https://www.epublicacoes.uerj.br/index.php/rcmccuerj/article/view/5345> Acessado em: de set. 2020.

BATALHA, M.O.; SILVA, A.L. Gerenciamento de sistemas agroindustriais: definições, especialidades e concorrentes metodológicas. In: Mário Otávio Batalha. (Org.). Gestão Agroindustrial - Volume 1. 3 ed. São Paulo: Editora Atlas, v 1, p. 25-73, 2007.

BERNARDO, C.H.C.; BERNARDES, J.C.; VIEIR, S.C.; LOURENZANI, A.E.B.S. Espaço rural e espaço urbano: pluralidade conceitual e as tecnologias de informação e comunicação. Revista Rua, n.23, v.1, p.141-153, 2017.

BRASIL. Constituição (1991). Lei no 8171, de 17 de janeiro de 1991. Dispõe Sobre A Política Agrícola... Brasília, 17 jan. 1991. Disponível em: <http://www.planalto.gov.br/ccivil_03/LEIS/L8171.htm>. Acessado em: 11 de jan. 2020. 
CARDOSO, R.L.; SILVEIRA, A. Contabilidade de ativos relevantes. Rio de Janeiro: FGV Editora, 2017

CASA DE AGRICULTURA DE LIMEIRA-SP. Produção animal média anual dos principais ativos biológicos presentes na EDR de Limeira (SP), 2019.

CASTRO, W.B.L.; FERREIRA, G.G.; CAMILLO, V.P.B. Evidenciação do CPC 29 e ias 41 - Ativo Biológico e produtos agrícolas: um estudo nas empresas listadas na bolsa de valores de São Paulo no ano de 2013. REVISTA LICEU ON-LINE, v.5, p. 45, 2015

COMITÊ DE PRONUNCIAMENTOS CONTÁBEIS - CPC. Pronunciamentos técnicos contábeis 2012. Brasília: Conselho Federal de Contabilidade, 2013.

CORRÊA, L. Você sabe o que é contabilidade digital? Disponível em: < https://www.jornalcontabil.com.br/voce-sabe-o-que-e-contabilidade-digital-por-luizcorrea/> Acessado em: 09 de set. 2020.

CREPALDI, S. A. Contabilidade rural -uma abordagem decisorial. São Paulo: Atlas, 2006.

CREPALDI, S.A. Contabilidade rural: uma abordagem decisorial. 8.ed. São Paulo: Atlas, 2016.

CREPALDI, S. A. Curso básico de Contabilidade. São Paulo: Ed. Atlas, 1995. 362 p.

CREPALDI, S.A. Contabilidade rural: uma abordagem decisorial. 7. ed. São Paulo, Atlas, 2012.

CRUZ, G.A.C. Tecnologias de Informação e Comunicação e sua relação com a agricultura - Chile. In: MASSRUHÁ, S.M.F.S. Tecnologia da informação e comunicação e suas relações com a agricultura. Brasília, DF: Embrapa, p. 353- 364, 2014

D'AMORE, D; CASTRO, A. S. Contabilidade geral. São Paulo:Brasiliense, 1976, 334p. Disponível em: <http://www.teses.usp.br/teses/disponiveis/12/12136/tde-19032012- 
185759/pt-br.php>Acessado em: 04 de Set 2020.

FERRAZ, C.O.; PINTO, W.F. Tecnologia da Informação para a Agropecuária: Utilização de Ferramentas da Tecnologia da Informação no Apoio a Tomada de Decisões em Pequenas Propriedades. RECoDAF - Revista Eletrônica Competências Digitais para Agricultura Familiar, Tupã, v. 3, n. 1, p. 38-49, jan./jun. 2017.

FRANCISCO, W. D. C. A modernização da Agricultura. Disponível em: $<$ https://educador.brasilescola.uol.com.br/estrategias-ensino/a-modernizacaoagricultura.htm> Acessado em: 15 de ago. 2020.

FRANCO, H. Contabilidade Geral. 23. ed. São Paulo: Atlas, 1997, 407 p.

FREITAS, E. $\quad$ Agronegócios. Disponível em: $<$ https://mundoeducacao.uol.com.br/geografia/agronegocios.htm> Acessado em: 15 de ago. 2020.

GELB, E.; VOET, H. ICT adoption trends in agriculture: a summary of the EFITA ICT adoption questionnaires (1999-2009). [2009]. Disponível em:

$<$ http://departments.agri.huji.ac.il/economics/voet-gelb.pdf>. Acesso em: 14 de fev. 2020.

GODINHO, R. F. A gestão de empresas rurais. Milkpoint, São Paulo, jun./2015. Disponível em: http://www.milkpoint.com.br/radar-tecnico/gerenciamento/agestao-deempresas-rurais-95522n.aspx Acessado em: 14 de ago. 2020.

GONÇALVES, E. C; BAPTISTA, E. Contabilidade geral. 7. ed. SãoPaulo: Atlas, 2011.

GREGOLIN, M.R.P. Apontamentos sobre o uso das Tecnologias de Informação e Comunicação na Extensão Rural: relatos acadêmicos e orientações internacionais RECoDAF - Revista Eletrônica Competências Digitais para Agricultura Familiar v. 5, n. 2 2019. IBGE Instituto Brasileiros de Geografia e Estatística. Censo Agro 2017: população ocupada nos estabelecimentos agropecuários cai 8,8\%. Disponível em: $<$ https://agenciadenoticias.ibge.gov.br/agencia-salade-imprensa/2013-agencia-de- 
noticias/releases/25789-censo-agro-2017-populacao-ocupada-nosestabelecimentosagropecuarioscai-8-

8\#: :text=No\%20Censo\%202017\%2C\%201.430.156,era\%20de\%20apenas\%2075\% 20mil> Acessado em: 02/07/2020.

HOLTZ, L; ALMEIDA, J. E. F. Estudo sobre a relevância e a divulgação dos ativos biológicos das empresas listadas na bm\&fbovespa. Sociedade, contabilidade e gestão. Rio de Janeiro, maio / agosto 2013. Disponível em: http://www.atena.org.br/revista/ojs-2.2.3-06/index.php/ufrj/article/view/1872. Acessado em: 05 set. 2020.

IAS 41- Ativo Biológico e produto agrícola: um estudo nas empresas listadas na bolsa de valores de São Paulo no ano de 2013. REVISTA LICEU ON-LINE, v.5, p.45, 2015.

IUDÍCIBUS, S. et al. Manual de Contabilidade das Sociedades por Ações: aplicável às demais sociedades. 7. ed. São Paulo: Atlas, 2008.

IUDICIBUS, S.D. Contabilidade Gerencial. 4. ed. São Paulo: Atlas, 1986. IUDíCIBUS, S.D. Teoria da Contabilidade. 11. ed. São Paulo: Atlas, 2015.

JACINTO, R. Contabilidade geral. São Paulo: Ática, 1990.

JIAMBALVO, J. Contabilidade Gerencial. Rio de Janeiro: LTC, 2002.

LASTRO. GEDAVE: 0 que é? Disponível em: <https://lastroagronegocios.com.br/gedave-o-que-e/> Acessado em: 30 de ago. 2021.

LOURENZANI, W. L.; LOURENZANI, A. E. B. S. Potencialidades do Agronegócio Brasileiro do Amendoim. In: Sociedade Brasileira de Economia e Sociologia Rural, 44, 2006. Anais do XLIV SOBER. Fortaleza: SOBER, 2006, 1 CD. Acessado em: 15 de ago. 2020.

MARINHO, A. Contabilidade Digital: o que é e quais são seus benefícios? 
Disponível em: <https://www.jornalcontabil.com.br/contabilidade-digital-o-que-e-equais-sao-seus-beneficios/> Acessado em: 09 de Set 2020.

MARION, J.C. Contabilidade rural. 14. ed. São Paulo: Atlas, 2014.

MARION, J.C. Contabilidade rural: contabilidade agrícola, contabilidade da pecuária. 14. ed. São Paulo: Atlas, 2017.

MARION, J.C. Contabilidade Rural. 6. ed. São Paulo: Atlas, 2000.

MARION, J.C. O Ensino da Contabilidade. 2. ed. São Paulo. Atlas, 2001.

MATTAR, F.N. Pesquisa de Marketing. São Paulo: Atlas, 1996.

MENDES, C.I.C.; BUAINAIN, A.M.; FASIABEN, M.C.R. Uso de computador e Internet nos estabelecimentos agropecuários brasileiros. In: MASSRUHÁ, S.M.F.S. Tecnologia da informação e comunicação e suas relações com a agricultura. Brasília, DF : DF: apa, p.39-52, 2014

NETO, M. D. C.; PINTO, P. A.; COELHO, J. P. P. TECNOLOGIAS DE INFORMAÇÃO E COMUNICAÇÃO E A AGRICULTURA. 1 ed. SPI - Sociedade Portuguesa de Inovação, Porto, 2005.

NIYAMA, J.K.; SILVA, C.A.T. Teoria da contabilidade. 3. ed., São Paulo: Atlas, 2013.

NOGUEIRA, D.R.; PIRES, P.A.S. Nível de Disclosure do CPC 29 ativos biológicos: análise dos fatores determinantes nas companhias brasileiras. Contabilidade, Gestão e Governança, Brasília, v. 20, n. 1, p. 38-54, jan./abr. 2017.Disponível em: <https://www.revistacgg.org/contabil/article/download/1103/pdf>. Acessado em: 7 de set. 2019.

OLIVEIRA, D.L; OLIVEIRA, G.D. Contabilidade rural: uma abordagem do agronegócio dentro da porteira. Curitiba: Juruá, 2017. 
OLIVEIRA, L. Demonstrações Contábeis: importância, quem usa e para que usar. Disponível em: <https://capitalsocial.cnt.br/demonstracoes-contabeis- importanciaquem-usa-e-para-que-usar/> Acessado em: 14 de ago. 2020.

OLIVEIRA, N.C. Contabilidade do agronegócio: teoria e prática. 2. ed. Curitiba: Juruá, 2014.

PADOVEZE, C.L. Contabilidade geral. Curitiba: Inter Saberes, 2016.

PADOVEZE, L.C; BENEDICTO, C.G; LEITE, J.S.J. Manual de Contabilidade Internacional: Teoria e Prática. ed. Cengage Learning. São Paulo, 2012. PEROVANO, D.G. Manual de metodologia da pesquisa científica. Curitiba: Inter Saberes, 2016.

PONTES, E.S. et al. Produção acadêmica nacional em contabilidade: análise das teses e dissertações produzidas entre 2007 e 2016. READ, Porto Alegre, v.23, n.3, p.239-258, set./dez. 2017. Disponível em:

<http://www.scielo.br/pdf/read/v23n3/1413-2311-read-23-3-239.pdf>. Acessado em: 7 de set. 2019.

PORTO, E. M. V.; GOLÇALVES, V. D. Agronegócio: a empresarural. Montes Claros, 2011. Disponível em: <https://central3.to.gov.br/arquivo/453224/> Acessado em: 14 de ago. 2020.

PRATA, B.C.; NOGUEIRA, D.R. Ativos biológicos e produtos agrícolas: uma análise bibliométrica sobre a produção nacional no período de 2009 a 2016. Revista de Informação Contábil, Porto Alegre, v.11, n.1, p. 76-91, jan./mar. 2017. Disponível em: <https://periodicos.ufpe.br/revistas/ricontabeis/article/download/230404/24544>. Acesso em: 8 set. 2019.

RECEITA FEDERAL - BRASIL. Instrução Normativa da Receita Federal número $1700 / 2017$. Acessado em: $<$ http://normas.receita.fazenda.gov.br/sijut2consulta/link.action?idAto=81268\&visao= 
a\%20notado> Acessado em: 12 dez. 2019

RECH, I. J. Formação do valor justo dos ativos biológicos sem mercado ativo: uma análise baseada no valor presente. 2011. Tese (Doutorado em Programa de Pósgraduação em ciências contábeis) -Universidade São Paulo. São Paulo.

RECH, I. J.; PEREIRA, I. V. Fair value: analysis of measurement methods applicable for fixed biological assets. Custos e agronegócio Online, v. 8, n. 2, p. 131-157, 2012. Disponível em: <https://anaiscbc.emnuvens.com.br/anais/article/download/4107/4108> Acessadoem: 04 de set. 2020.

RECH, I. J; CUNHA, M. F.; PEREIRA, I. V.; OLIVEIRA, J. R. Impostos diferidos: Um estudo dos impostos originados da avaliação dos ativos biológicos pelo valor justo na de pecuária. In: Congresso USP de Controladoria e Contabilidade, IV., 2006, SãoPaulo. Anais... São Paulo: 2006. Disponível em zem: <www.congressousp.fipecafi.org/artigos62006/443.pdf> Acessado em: 6 set. de 2020.

RIBEIRO, O. M. Contabilidade geral fácil. 9. ed. São Paulo: Saraiva, 2013.

RIBEIRO, V. M. A IMPORTÂNCIA DO CONTADOR NA GESTÃO DO EMPREENDIMENTO RURAL. Disponível em: < http://repositorio.fucamp.com.br/jspui/bitstream/FUCAMP/492/1/Importanciacontador gestao.pdf> Acessado em: 09 de set. 2020.

RICHARDSON, R.J. Pesquisa social: métodos e técnicas. São Paulo: Atlas, 2008.

ROSENFELD, H. et al. Gestão do desenvolvimento de produtos: uma referência para melhoria dos processos. São Paulo: Saraiva, 2006.

SÁ, A. L. Teoria da Contabilidade. São Paulo: Atlas, 1998. 349 p

SCHULTZ, F. Contabilidade digital: como funciona e quais as vantagens desse modelo? Disponível em: < https://bomcontrole.com.br/contabilidade-digital- como- 
funciona/> Acessado em: 09 de set. 2020

SOARES, I. $O$ que é a contabilidade digital? Disponível em: <https://www.contabeis.com.br/artigos/5753/o-que-e-a-contabilidadedigital/>Acessado em: 09 de set. 2020.

SOUZA, F.J.V. et al. Produção científica sobre ativos biológicos e produtos agrícolas: um estudo entre os anos de 2006 e 2011. Custos e agronegócio, Recife, v.9, n.1, p.3-15, jan./mar. 2013. Disponível em:

$<$ http://www.custoseagronegocioonline.com.br/numero1v9/Publicacoes.pdf $>$.Acessado em: 7 de set. 2019.

SUPTITZ, L. A. S.; WOBETO, M. C. R.; HOFER. E. Gestão de custos na suinocultura: um estudo de caso. XV Congresso Brasileirode Custos -Curitiba -PR, Brasil, 12 a 14 de novembro de 2008. Disponível em:

$<w w w . c o n g r e s s o d e c u s t o s . c o m . b r / t e x t o / v i e w p u b l i c ? I D \_T E X T O=2709 .>\quad$ Acessado em: 10 de set. 2020

SZUSTER, F. R.; SZUSTER, F. R. Contabilidade geral: introdução à Contabilidade Societária. 4. ed. São Paulo: Atlas, 2013 técnicos contábeis 2012. Disponível em: < http://static.cpc.aatb.com.br/Documentos/324_CPC_29_rev\%2014.pdf> Acessado em: 15 de jan. 2020.

T\&M - Assessoria Contábil. O que é o CAR? Disponível em: < https://www.contabilidadetm.com.br/pergunta/o-que-e-o-car/> Acessado em: 30 de ago. 2021.

ULRICH, E. R. Contabilidade rural e perspectivas da Gestão no agronegócio.Rev. De Administração e Ciências Contábeis do IDEAU, v. 4, n. 9, Jun. - Dez., 2009. Disponível em:

$<$ http://www.ideau.com.br/getulio/restrito/upload/revistasartigos/108_1.pdf> Acessado em: 25 de jul. de 2020.

VALE, N.K.A.; SILVA, K.L.J. Contabilidade rural: apoio e controle para o processo de 
gestão das empresas rurais de pequeno porte da microrregião de Iporá-GO. Revista UNEMAT de Contabilidade, p.20-34, v. 8, n. 15, 2019.

VICECONTI, P.; NEVES, S.D. Contabilidade Básica. 16aㅗ ed. Editora: Saraiva, São Paulo, 2013.

VIEIRA, G.A. Resenha dos livros: Tecnologias da informação e comunicação e suas relações com a agricultura, de Sílvia Massruhá et al. e Agricultura de precisão, de Alberto Bernardi et al. TECCOGS, n. 20, 2019.

YIN, R.K. Estudo de Caso - Planejamento e Métodos. 2a ed. Bookman: Porto Alegre, 2001.

YOSHITAKE, M; TINOCO, J.E.P; FRAGA, M.S. O custo do ativo biológico: estudo de caso da Sanco S.A. usina de açúcar e álcool. In: CONGRESSO BRASILEIRO DE CUSTOS, 21, 2014, Natal. Anais CBC. São Leopoldo, RS: CBC, 2014. Disponível em: $<$ http://anaiscbc.emnuvens.com.br/anais/article/download/3844/3845> Acesso em: 8 set. 2019.

ZANIN, A; FAVRETTO, J; POSSA, A; MAZZIONI, S; ZONATTO, V.C.S. Apuração e custos e resultados econômicos no manejo da produção leiteira: uma análise comparativa entre o sistema tradicional e o sistema freestall. Organizações Rurais \& Agroindustriais, v. 17, p. 431-444, 2015.

ZUIN, L.F.S; ZUNIN, P.B; QUEIROZ, T.R. A construção de novos caminhos para a gestão, inovação e sustentabilidade nos agronegócios. In: Luís Fernando Soares Zuin; Timóteo Ramos Queiroz. (Org.). Agronegócios: gestão, inovação e sustentabilidade. $2^{\mathrm{a}}$ ed. São Paulo: Editora Saraiva, 2019, v.1, p. 2-20.

ZUIN, L.F.S.; ZUIN, P.B.; COSTA, M.J.R.P. Comunicação dialógica para os processos produtivos nos agronegócios. In: Luís Fernando Soares Zuin; Timóteo Ramos Queiroz. (Org.). Agronegócios: gestão, inovação e sustentabilidade. 2ed.São Paulo: Editora Saraiva, 2019, v. 1, p. 39-55. 
ZUIN, L.F.S.; ZUIN, P.B. Comunicação dialógica na gestão ambiental: novos caminhos metodológicos para a extensão rural. In: PALHARES, J.C.P.; GEBLER, L. (Org.). Gestão Ambiental na Agropecuária. 1ed.Brasília: Embrapa Informação Tecnológica, 2014, v. 2, p. 13-48. 


\section{ANEXO \\ Caminhos para a internalização da prática contábil ativo biológico empequenas e médias propriedades rurais roteiros de pesquisa.}

\section{a) Produtores Rurais}

1. Caracterização dos produtores rurais:

a) Idade:

b) Cidade:

c) Sexo: ( ) Masculino, ( ) Feminino

d) Educação forma?

e) Tamanho da propriedade?

f) O que produz?

g) Faz parte de alguma associação e/ou cooperativa?

h) Caso a resposta seja positiva a quanto tempo a integra?

i) Quais produtos a cooperativa/associação produz?

j) Como foi formada a cooperativa/associação?

k) Quais os maiores desafios e novos projetos da cooperativa/associação?

1. De forma ampla quais são as principais dificuldades dos produtores rurais de pequeno e médio porte, organizados em associações e cooperativas ou independentes, em formalizar os seus processos produtivos por meio de documentos e planilhas?

2. Quais são as principais dificuldades que os produtores rurais de pequeno e médio porte, organizados em associações e cooperativas ou independentes, possuem em internalizar a prática da formalização dos processos produtivos em suas rotinas de trabalho?

3. O produtor rural de pequeno e médio porte, organizados em associações e cooperativas ou independentes, acredita na importância das práticas contábeis (fluxo de caixa, entre outras) para a sobrevivência e melhoria das suas rotinas produtivas e empreendimento? 
4. Por que esses sujeitos não aplicam nas suas rotinas gerenciais as práticas contábeis (fluxo de caixa, entre outras)?

5. O produtor rural objeto desse estudo possui consciência que algumas práticas contábeis como o Ativo Biológico pode trazer benefícios fiscais e monetários para o seu empreendimento?

6. Que tipo de encaminhamentos você sugere para alterar essa realidade gerencial na produção agropecuária de pequeno e médio porte, organizados em associações e cooperativas ou independentes?

7. O produtor rural possui algum conhecimento sobre o Ativo Biológico em seu regime de contabilidade?

\section{b) Contador}

a. Idade:

b. Sexo: Masculino ( ) Feminino ( )

c. Formação: além da graduação de contador: Pós-graduação:

d. Função na empresa:

e. Há quanto tempo trabalha na empresa:

1. Possui algum cliente ou trabalha em empresa que desenvolve a contabilidade rural, ou seja, adesão ao CPC - 29 - Ativo Biológico?
( ) Sim
) Não
( ) Outro

2. Qual o seu nível de conhecimento sobre a contabilidade rural e do CPC 29 Ativo Biológico?
( ) Básico
( ) Intermediário
( ) Avançado
( ) Nenhum conhecimento
( ) Outro

1. Em seu entendimento qual a maior dificuldade em mensurar o valor justo de mercado para ativos biológicos de pequenos e médios produtores ruraispertencentes ou não a associações ou cooperativas?

2. Você como contador possui conhecimento sobre o CPC 29 e suas 
obrigatoriedades?

3. Qual o regime tributário adotado pelo pequeno e médio produtor rural que são seus clientes?

4. Elabora os demonstrativos contábeis/balanço, DRE e fluxo de caixa, para os pequenos e médios empresários rurais que presta serviços?

5. Utiliza alguma ferramenta de gestão na atividade rural dos pequenos e médios empresários rurais, aos quais presta serviços?

6. Participou de algum treinamento/palestra sobre o assunto Ativo Biológico?

7. Na atividade rural, o que é mais importante na sua opinião e conhecimento técnico ou de gestão? Relate sobre isto.

8. Como reconhece as oscilações de preços de mercado na propriedade dos pequenos e médios empresários rurais, já que os ativos são commodities e sujeitos a variação de paridade de moedas internacionais?

9. Na sua opinião quais seriam os principais entraves para a internalização desta prática contábil nas empresas rurais de pequeno e médio porte? Pertencentes ou não a cooperativas/associações. Quanto a maturidade de sua rotina contábil?

10. Quais os pré-requisitos relativos a coleta e armazenamento de dados e informações que os produtores rurais de pequenos e médios portes devem introduzir em suas rotinas produtivas para serem empregados no desenvolvimento do seu Pronunciamento Técnico CPC 29?

11. Para o pequeno e médio produtor rural, pertencente ou não a associações ou cooperativas, geralmente seu modelo contábil é o "regime de caixa". Entretanto esse modelo não oferta informações necessárias para os "stakeholders" (Bancos, financeiras, fornecedores e clientes) tomarem conjunto de decisões a respeito da quantidade de oferta de crédito, de oferta de venda de produção e também da compra de insumos agropecuários para suas rotinas produtivas. Quais as dificuldades e desafios para esses produtores rurais alterarem o seu modelo contábil do "regime de caixa" para a "contabilidade formal"?

12. Mesmo utilizando a forma de aquisição como - financiamento, empréstimos, 
penhor rural, para maquinário, veículos, tratores, sementes, tecnologia, ainda prefere efetuar os mesmos na pessoa física e não na jurídica? Quais os motivos elencados pelos produtores?

13. Qual seria o real motivo, de possuírem bens de valor agregado (tratores, equipamentos, sementes, barracões, plantação, animais (matrizes), não contratam apólices de seguros agrícolas?

\section{C) Extensionistas rurais}

1. Caracterização dos técnicos extensionistas da pesquisa.

a) Idade:

b) Sexo: ( ) Masculino, ( ) Feminino

c) Formação: graduação

pós-graduação

d) Função

na

empresa:

e) Há quanto tempo trabalha e/ou pesquisa com a temática dos cursos/consultorias que ministra na empresa?

2. De forma ampla quais são as principais dificuldades dos produtores rurais de pequeno e médio porte, organizados em associações e cooperativas ou independentes, em formalizar os seus processos produtivos por meio de documentos e planilhas?

3. Quais são as principais dificuldades que os produtores rurais de pequeno e médio porte, organizados em associações e cooperativas ou independentes, possuem em internalizar a prática da formalização dos processos produtivos em suas rotinas de trabalho?

4. O produtor rural de pequeno e médio porte, organizados em associações e cooperativas ou independentes, acredita na importância das práticas contábeis para a sobrevivência e melhoria das suas rotinas produtivas e empreendimento? 
5. Por que esses sujeitos não aplicam nas suas rotinas gerenciais as práticas contábeis?

6. O produtor rural objeto desse estudo possui consciência que algumas práticas contábeis como o Ativo Biológico pode trazer benefícios fiscais e monetários para o seu empreendimento?

7. Que tipo de encaminhamentos você sugere para alterar essa realidade gerencial na produção agropecuária de pequeno e médio porte, organizados em associações e cooperativas ou independentes? 